\title{
Arctic smoke - record high air pollution levels in the European Arctic due to agricultural fires in Eastern Europe in spring 2006
}

\author{
A. Stohl ${ }^{1}$, T. Berg ${ }^{1, *}$, J. F. Burkhart ${ }^{1,2}$, A. M. Fjæraa ${ }^{1}$, C. Forster ${ }^{1}$, A. Herber ${ }^{3}$, Ø. Hov ${ }^{4}$, C. Lunder ${ }^{1}$, \\ W. W. McMillan ${ }^{5}$, S. Oltmans ${ }^{6}$, M. Shiobara ${ }^{7}$, D. Simpson ${ }^{4}$, S. Solberg ${ }^{1}$, K. Stebel ${ }^{1}$, J. Ström ${ }^{8}$, K. Tørseth ${ }^{1}$, \\ R. Treffeisen ${ }^{3}$, K. Virkkunen ${ }^{9,10}$, and K. E. Yttri ${ }^{1}$ \\ ${ }^{1}$ Norwegian Institute for Air Research, Kjeller, Norway \\ ${ }^{2}$ University of California, Merced, USA \\ ${ }^{3}$ Alfred Wegener Institute, Bremerhaven, Germany \\ ${ }^{4}$ Meteorological Institute, Oslo, Norway \\ ${ }^{5}$ University of Maryland, Baltimore, USA \\ ${ }^{6}$ Earth System Research Laboratory, NOAA, Boulder, USA \\ ${ }^{7}$ National Institute of Polar Research, Tokyo, Japan \\ ${ }^{8}$ Department of Applied Environmental Science, Stockholm University, Sweden \\ ${ }^{9}$ Arctic Centre, University of Lapland, Finland \\ ${ }^{10}$ Department of Chemistry, University of Oulu, Oulu, Finland \\ * now at: Norwegian University of Science and Technology, Trondheim, Norway
}

Received: 14 September 2006 - Published in Atmos. Chem. Phys. Discuss.: 5 October 2006

Revised: 8 January 2007 - Accepted: 19 January 2007 - Published: 26 January 2007

\begin{abstract}
In spring 2006, the European Arctic was abnormally warm, setting new historical temperature records. During this warm period, smoke from agricultural fires in Eastern Europe intruded into the European Arctic and caused the most severe air pollution episodes ever recorded there. This paper confirms that biomass burning (BB) was indeed the source of the observed air pollution, studies the transport of the smoke into the Arctic, and presents an overview of the observations taken during the episode. Fire detections from the MODIS instruments aboard the Aqua and Terra satellites were used to estimate the BB emissions. The FLEXPART particle dispersion model was used to show that the smoke was transported to Spitsbergen and Iceland, which was confirmed by MODIS retrievals of the aerosol optical depth (AOD) and AIRS retrievals of carbon monoxide (CO) total columns. Concentrations of halocarbons, carbon dioxide and $\mathrm{CO}$, as well as levoglucosan and potassium, measured at Zeppelin mountain near Ny Ålesund, were used to further corroborate the BB source of the smoke at Spitsbergen. The ozone $\left(\mathrm{O}_{3}\right)$ and $\mathrm{CO}$ concentrations were the highest ever observed at the Zeppelin station, and gaseous elemental mercury was also elevated. A new $\mathrm{O}_{3}$ record was also set at a station on Iceland. The smoke was strongly absorbing black carbon concentrations were the highest ever recorded
\end{abstract}

Correspondence to: A. Stohl

(ast@nilu.no) at Zeppelin - and strongly perturbed the radiation transmission in the atmosphere: aerosol optical depths were the highest ever measured at Ny Ålesund. We furthermore discuss the aerosol chemical composition, obtained from filter samples, as well as the aerosol size distribution during the smoke event. Photographs show that the snow at a glacier on Spitsbergen became discolored during the episode and, thus, the snow albedo was reduced. Samples of this polluted snow contained strongly elevated levels of potassium, sulphate, nitrate and ammonium ions, thus relating the discoloration to the deposition of the smoke aerosols. This paper shows that, to date, BB has been underestimated as a source of aerosol and air pollution for the Arctic, relative to emissions from fossil fuel combustion. Given its significant impact on air quality over large spatial scales and on radiative processes, the practice of agricultural waste burning should be banned in the future.

\section{Introduction}

The European sector of the Arctic saw unprecedented warmth during the first months of the year 2006. At Ny Ålesund on the island of Spitsbergen in the Svalbard archipelago, the monthly mean temperatures from January to May were $10.7,3.8,1.4,10.3$, and $4.2^{\circ} \mathrm{C}$ above the corre-

Published by Copernicus GmbH on behalf of the European Geosciences Union. 


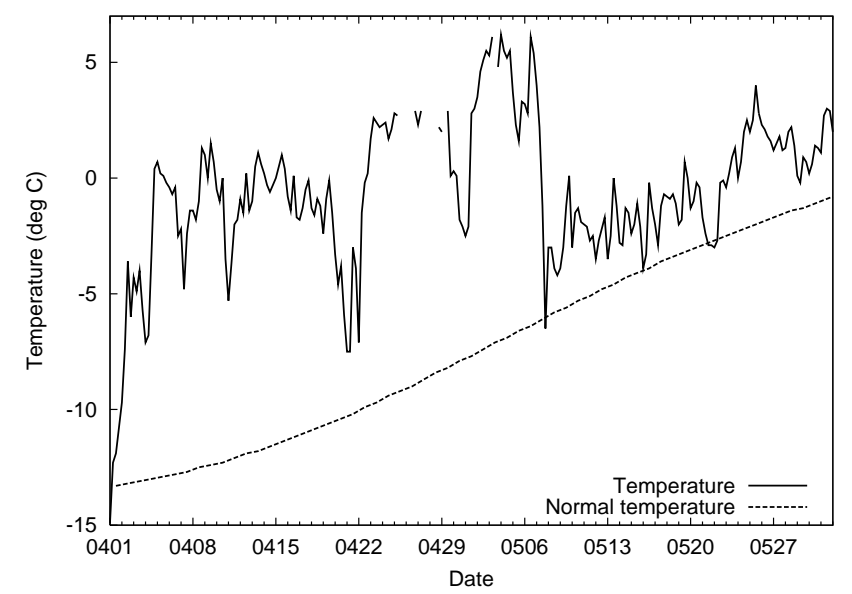

Fig. 1. Time series of the 2-m air temperatures at Ny Ålesund on Spitsbergen measured at 00:00, 06:00, 12:00 and 18:00 UTC, from 1 April to 1 June 2006 (solid line). Shown for reference is the climatological mean temperature since 1969 for the same time period (dashed line).

sponding values averaged over the period since 1969 (Meteorological Institute, 2006); the January, April and May values were the highest ever recorded. Figure 1, a comparison between the temperatures measured at Ny Ålesund in April and May 2006 with the corresponding climate mean, shows that the entire two months were warmer than normal. Due to the abnormal warmth, the seas surrounding the Svalbard archipelago were almost completely free of closed ice at the end of April, for the first time in history. In contrast to the Arctic, the European continent saw a delayed onset of spring in 2006. Snow melt in large parts of Europe occurred only in April; even as late as 1 May, snow covered much of Scandinavia.

Related to the abnormal warmth in the Arctic, record-high levels of air pollution were measured at the Zeppelin station near Ny Ålesund on Spitsbergen. It will be shown in this paper that they were caused by transport of smoke from agricultural fires in Eastern Europe. The most severe air pollution episodes happened on 27 April and during the first days of May 2006 when the concentrations of most measured air pollutants (aerosols, $\mathrm{O}_{3}$, etc.) exceeded the previously recorded long-term maxima. Views from the Zeppelin station clearly showed the decrease in visibility from the pristine conditions on 26 April to when the smoke engulfed Svalbard on 2 May (Fig. 2). Iceland, where a new $\mathrm{O}_{3}$ record was set at the Storhofdi station, was also affected by the smoke plume.

\section{Arctic air pollution}

Because of its remoteness, the Arctic troposphere was long believed to be extremely clean but in the 1950s, pilots flying over the North American Arctic discovered a strange haze (Greenaway, 1950; Mitchell, 1957), which decreased visi-

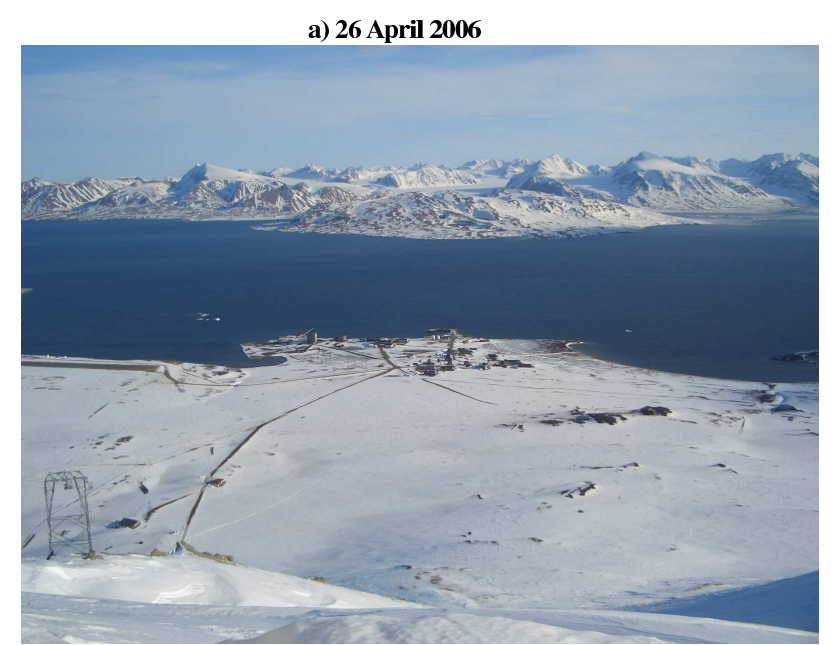

b) 2 May 2006

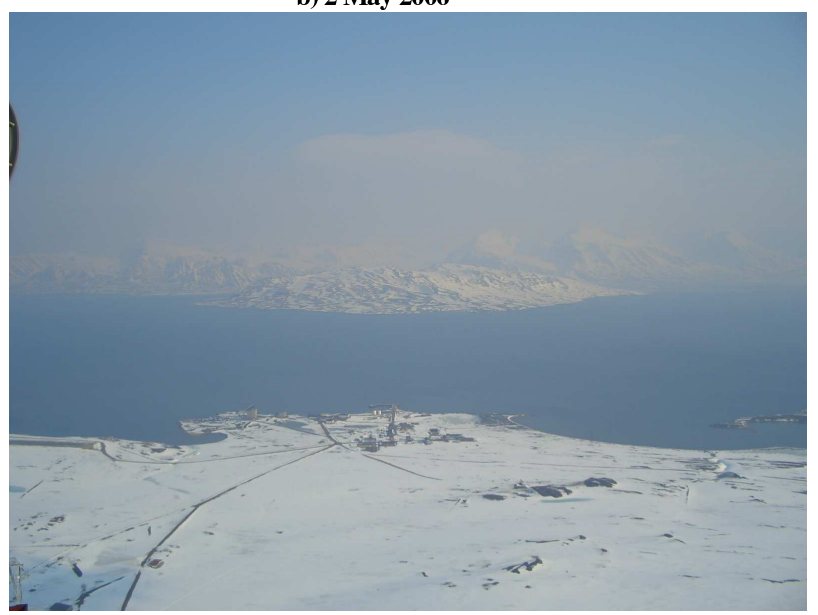

Fig. 2. View from the Zeppelin station (a) under clear conditions on 26 April, and (b) during the smoke episode on 2 May 2006. Image courtesy of Ann-Christine Engvall.

bility significantly. The Arctic Haze, accompanied by high levels of gaseous air pollutants (e.g., hydrocarbons; Solberg et al., 1996), was observed regularly since then and is a result of the special meteorological situation in the Arctic in winter and early spring (Shaw, 1995). Temperatures at the surface become extremely low, leading to a thermally very stable stratification with frequent and persistent occurrences of surface-based inversions (Bradley, 1992) that reduce turbulent exchange, hence dry deposition. The extreme dryness minimizes wet deposition, thus leading to very long aerosol lifetimes in the Arctic in winter and early spring. After polar sunrise, photochemical activity increases and can produce phenomena such as the depletion of $\mathrm{O}_{3}$ and gaseous elemental mercury (GEM) (Lindberg et al., 2002).

Surfaces of constant potential temperature form closed domes over the Arctic, with minimum values in the Arctic boundary layer (Klonecki et al., 2003). This transport barrier isolates the Arctic lower troposphere from the rest of the atmosphere. Meteorologists realized that in order to facilitate 
isentropic transport, a pollution source region must have the same low potential temperatures as the Arctic Haze layers (Carlson, 1981; Iversen, 1984; Barrie, 1986). For gases and aerosols with lifetimes of a few weeks or less, this rules out most of the world's high-emission regions as potential source regions because they are too warm, and leaves northern Eurasia as the main source region for the Arctic Haze (Rahn, 1981; Barrie, 1986; Stohl, 2006). Transport from Eurasia is highly episodic and is often related to large-scale blocking events (Raatz and Shaw, 1984; Iversen and Joranger, 1985).

Boreal forest fires are another large episodic source of Arctic air pollutants, particularly of black carbon (BC) (Lavoué et al., 2000), which has important radiative effects in the Arctic, both in the atmosphere and if deposited on snow or ice (Hansen and Nazarenko, 2004). They occur in summer when wet and dry deposition are relatively efficient and the Arctic troposphere is generally cleaner than in winter. Nevertheless, an aircraft campaign in Alaska frequently sampled aerosol plumes from Alaskan and maybe also Siberian forest fires (Shipham et al., 1992), and a PhD thesis suggests that BC observations at Arctic sites are linked to boreal forest fires (Lavoué, 2000). Recently, Stohl et al. (2006) showed that severe forest fires burning in Alaska and Canada led to strong pan-Arctic increases in light absorbing aerosol concentrations during the summer of 2004.

\section{Observations}

We present measurements mostly from the research station Zeppelin $\left(11.9^{\circ} \mathrm{E}, 78.9^{\circ} \mathrm{N}, 478 \mathrm{~m}\right.$ a.s.1.). The station is situated in an unperturbed Arctic environment on a ridge of Zeppelin mountain on the western coast of Spitsbergen. Because of the altitude difference and the generally stable atmospheric stratification, contamination from the nearby small settlement of Ny Ålesund (located near sea level) is minimal at Zeppelin.

Hourly $\mathrm{O}_{3}$ concentrations were recorded by UVabsorption spectrometry (API 400A). GEM was measured using a Tekran gas phase mercury analyzer (model 2537A) as described in Berg et al. (2003). CO was measured using a RGA3 analyzer (Trace Analytical) fitted with a mercuric oxide reduction gas detector. Five ambient air measurements and one field standard were performed every $2 \mathrm{~h}$. The field standards were referenced against a Scott-Marine Certificated standard and a calibration scale (Langenfelds et al., 1999; Francey et al., 1996).

Carbon dioxide $\left(\mathrm{CO}_{2}\right)$ was measured using a Nondispersive Infrared Radiometer (NDIR), Li-COR model 7000. The radiometer was run in differential mode using a reference gas with a $\mathrm{CO}_{2}$ content near the measured concentrations. Roughly every $2 \mathrm{~h}$ the radiometer was calibrated using three different $\mathrm{CO}_{2}$ concentrations spanning the expected atmospheric concentration interval. Halocarbons were analyzed by gas chromatography/mass spectroscopy (Agilent,
5793 N) at 4-hourly intervals. Substances from 21 of air were preconcentrated on an automated adsorption-desorption system filled with three different adsorbents. This preconcentration unit was developed by the University of Bristol (Simmonds et al., 1995) and has been in operation in the AGAGE network for several years (Prinn et al., 2000).

The particle size distributions were measured using a Differential Mobility Particle Sizer (DMPS) consisting of a Differential Mobility Analyser (Knutson and Whitby, 1975) and a TSI 3010 particle counter. The sheath flow is a closedloop system (Jokinen and Makela, 1997). DMPS data from Zeppelin have been presented previously (Ström et al., 2003) and cover the size range from 13.5 to $700 \mathrm{~nm}$ diameter (bin limits).

Information on light absorbing particles was gathered with a custom-built particle soot absorption photometer (PSAP). In this instrument, light at $530 \mathrm{~nm}$ wavelength illuminates two $3 \mathrm{~mm}$ diameter spots on a single filter substrate, on one of which particles are collected from ambient air flushed through the filter, and the other kept clean as a reference. The change in light transmittance across the filter is measured to derive the particle light absorption coefficient $\sigma_{a p}$, ignoring the influence of scattering particles. Conversion of $\sigma_{a p}$ to $\mathrm{BC}$ concentrations requires the assumptions that all the light absorption measured is from $\mathrm{BC}$, and that all $\mathrm{BC}$ has the same light absorption efficiency. We convert $\sigma_{a p}$ values to equivalent $\mathrm{BC}(\mathrm{EBC})$ mass concentrations using a value of $10 \mathrm{~m}^{2} \mathrm{~g}^{-1}$, typical of aged BC aerosol (Bond et al., 2005).

Aerosol filter samples were collected for subsequent analysis of the aerosols' content of anions $\left(\mathrm{Cl}^{-}, \mathrm{NO}_{3}^{-}, \mathrm{SO}_{4}^{2-}\right)$ and cations $\left(\mathrm{Ca}^{2+}, \mathrm{Mg}^{2+}, \mathrm{K}^{+}, \mathrm{Na}^{+}, \mathrm{NH}_{4}^{+}\right)$on a daily basis using an open face NILU filter holder, loaded with a $47 \mathrm{~mm}$ diameter Teflon filter (Zefluor $2 \mu \mathrm{m}$ ). The cations and anions were quantified by ion chromatography. While $\mathrm{NO}_{3}^{-}$ and $\mathrm{NH}_{4}^{+}$are subject to both positive and negative biases, we only report the sum of particulate and gaseous phases for the two. For conditions typical for Norway, the particulate phase is the dominant fraction accounting for 80-90\% of $\mathrm{NO}_{3}^{-}$and approximately $90 \%$ of $\mathrm{NH}_{4}^{+}$. Aerosol samples were also collected on $8^{\prime \prime} \times 10^{\prime \prime}$ cellulose filters (Whatman 41) according to a $2+2+3$ days weekly sampling scheme, using a high volume sampler with a $2.5 \mu \mathrm{m}$ cut off. Using these samples, the aerosols' content of levoglucosan was analyzed with high performance liquid chromatography combined with time-offlight high-resolution mass spectrometry (HPLC/HRMS) as described by Dye and Yttri (2005). Finally, weekly aerosol samples were collected using a Leckel SEQ47/50 sampler loaded with prefired quartz fibre filters. The samples' content of elemental carbon (EC) and organic carbon (OC) was quantified using the NIOSH 5040 thermo-optical method (Birch and Cary, 1996), which accounts for pyrolytically generated EC during the analysis.

At Ny Ålesund, daylight measurements of the spectral aerosol optical depth (AOD) were made with the automatic 
sun photometer SP1A which uses the imaging method of Leiterer and Weller (1988). Seventeen channels cover the spectral range from 350 to $1065 \mathrm{~nm}$ with a full-width-halfmaximum of 5 to $15 \mathrm{~nm}$. The accuracy of the measured AOD is between 0.005 and 0.008 . The measurement time is less than $5 \mathrm{~s}$ but the data presented here are hourly mean values. More details can be found in Herber et al. (2002).

A Micro-Pulse Lidar Network (MPLNET) instrument (Welton et al., 2001) is operated for the National Institute of Polar Research (Japan) at Ny Ålesund by the Alfred Wegener Institute for Polar and Marine Research, Germany, since 2002. The MPL uses a Nd/YLF laser, emitting laser light at a wavelength of $523.5 \mathrm{~nm}$. Details regarding on-site maintenance, calibration techniques, description of the algorithm used and data products are given in Campbell et al. (2002). We present the corrected normalized relative backscatter signal, which corresponds to the raw signal counts from the MPL, processed to remove all instrument related parameters except the calibration constant. Since the molecular return gives rise to a range-corrected signal decrease of $50 \%$ between ground and $5 \mathrm{~km}$ altitude due to the molecular density decrease, we normalized the relative backscatter with the molecular return using a standard-atmospheric density profile. The data are stored at 1 minute time resolution and 30 $\mathrm{m}$ vertical resolution.

In addition to the measurements from Spitsbergen, we also present surface $\mathrm{O}_{3}$ measurements from Storhofdi $\left(20.34^{\circ} \mathrm{W}\right.$, $63.29^{\circ} \mathrm{N}, 127 \mathrm{~m}$ a.s.l.) on the southernmost tip of the island of Heimay in the Westman Islands, a group of small volcanic islands to the south of the principal island of Iceland. The preponderance of airflow is from off the Atlantic Ocean and there is only a small population center about $5 \mathrm{~km}$ north of the measurement site. Ozone measurements are made using a Thermo Environmental Instruments (TEI) model 49C analyzer, which has been regularly intercompared with a secondary standard $\mathrm{O}_{3}$ analyzer maintained by the NOAA Earth System Research Laboratory, Global Monitoring Division. This secondary standard is calibrated against a standard reference $\mathrm{O}_{3}$ photometer maintained by the U.S. NIST.

For studying the transport and geographical extent of the aerosol pollution, we also used satellite measurements. Total column CO was retrieved from the Atmospheric InfraRed Sounder (AIRS) in orbit onboard NASA's Aqua satellite. All AIRS retrievals for the given days were binned to a $1 \times 1^{\circ}$ grid. The prelaunch AIRS CO retieval algorithm was employed using the AFGL standard CO profile as the first guess and the AIRS team retrieval algorithm PGE v4.0. Although AIRS CO retrievals are most sensitive to the midtroposphere, the broad averaging kernel can be influenced by enhanced $\mathrm{CO}$ abundances near the boundary layer (McMillan et al., 2005, 2006 ${ }^{1}$ ).

\footnotetext{
${ }^{1}$ McMillan, W. W., Warner, J. X., McCourt Comer, M., Maddy, E., Chu, A., Sparling, L., Eloranta, E., Hoff, R., Sachse, G., Barnet, C., Razenkov, I., and Wolf, W.: AIRS views of transport from 10-
}

The daily level 3 AOD data at a wavelength of $550 \mathrm{~nm}$, retrieved with algorithm MOD08_D3 from the MODIS Terra Collection 4, were also used. A description and validation of these data can be found in Remer et al. (2005) and Ichoku et al. (2005). Their stated accuracy is $\pm(0.05+0.2 \times$ AOD $)$ over land and $\pm(0.03+0.05 \times \mathrm{AOD})$ over ocean. Retrievals are not being made in cloudy areas, or in regions with a high surface albedo, e.g. over most of snow-covered Norway, and in ice-covered parts of the Arctic.

\section{Biomass burning emissions}

In April and May 2006, a large number of fires occurred in the Baltic countries, western Russia, Belarus, and the Ukraine. The fires were started by farmers who burned their fields before the start of the new growing season. This practice is illegal in the European Union but is still widely used in Eastern Europe for advancing crop rotation and controlling insects and disease. It is quite common that agricultural fires get out of control and devastate nearby forests or human property. According to newspaper reports (see http://www.baltictimes.com), the fires burned into the forests of the nature preserve Kuronian Spit in Lithuania and could be extinguished only after considerable efforts. Five people died in the fires in Latvia.

For estimating biomass burning (BB) emissions from these fires, we used active fire detections by the MODIS instruments onboard the Aqua and Terra satellites. These detections are based on MODIS Collection 4 data and the MOD14 and MYD14 algorithms (Giglio et al., 2003) (see http://maps.geog.umd.edu/products/MODIS Fire_Users_Guide_2.2.pdf). A number between 0 and 100 characterizes the confidence for every fire detection. We only used detections with a confidence level greater than 75 . The algorithm uses data from pixels of about $1 \mathrm{~km}^{2}$ size but the actual fire size is not known. Fires of $1000 \mathrm{~m}^{2}$ or less can be detected under good observing conditions but even large fires can be obscured by clouds. Furthermore, detections can only be made at the time of the satellite overpasses and the number of detections also depends on the minimum confidence level requested. In the absence of better information, we assumed that every detection represents a burned area of 180 ha, based on a statistical analysis of MODIS fire detections with independent area burned data by Wotawa et al. (2006). This shall account both for the area burned by the detected fire itself and undetected fires in its vicinity on the same day.

Figure 3 shows the daily number of the detected fires in the region north of $40^{\circ} \mathrm{N}$ and between 20 and $60^{\circ} \mathrm{E}$. More than 300 fires/day were detected from 25 April to 6 May 2006, with a peak of more than 800 detections on 2 May. This

23 July 2004 Alaskan/Canadian fires: Correlation of AIRS CO and MODIS AOD and comparison of AIRS CO retrievals with DC-8 in situ measurements during INTEX-NA/ICARTT, J. Geophys. Res., submitted, 2006. 


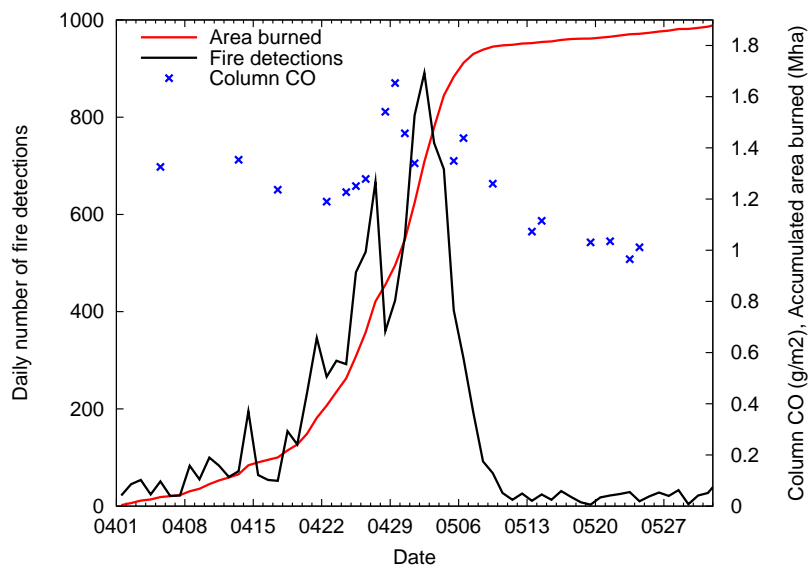

Fig. 3. Time series of daily number of MODIS fire detections in the region north of $40^{\circ} \mathrm{N}$ and between $20^{\circ} \mathrm{E}$ and $60^{\circ} \mathrm{E}$ (black line) and estimated area burned in this region, accumulated from 1 April 2006 and assuming that 180 ha burned per detected fire (red line). Also shown are measurements of total column CO taken at Zvenigorod (blue symbols).

leads to an estimate of almost 2 million hectare burned in April and May 2006. The decrease in the number of fire detections on 28-30 April is likely not due to an actual decrease in fire activity but to the presence of clouds near $32^{\circ} \mathrm{E}$ and $54^{\circ} \mathrm{N}$. In a crude attempt to account for the cloud effect on 28-30 April, we doubled the fire pixels in a small area to the northeast of the clouds and shifted these "shadow" pixels to the southwest into the cloud band. This increased the number of detections by about $40 \%$ on 28 and 29 April and $10 \%$ on 30 April. This correction was not applied to the data shown in Fig. 3 but was used for all subsequent calculations.

Figure 4 shows time series of the surface temperature and snow depth (shown as mm water equivalent), averaged over the region where most of the fires burned. There was a lot of snow on the ground until the end of March, which started melting in April. The fire frequency increased dramatically on 21 April (see Fig. 3), after all the snow had disappeared. Korontzi et al. (2006) show that spring-time agricultural burning in Eastern Europe peaked in March in the year 2002 and in April in the years 2001 and 2003, whereas in all three years there was very little burning in May. In 2002, a smoke episode caused by agricultural fires in this region was observed in Finland already in the middle of March (Niemi et al., 2004). In 2006, in contrast, farmers were forced to wait with the burning for the unusually late snow melt, causing a strong emission pulse at the end of April/beginning of May (see Fig. 3) when fields were quickly prepared for the already delayed sowing. This is demonstrated also by the infrared spectroscopy measurements of total column $\mathrm{CO}$ made at Zvenigorod $\left(36^{\circ} \mathrm{E}, 55^{\circ} \mathrm{N}\right.$; see Yurganov et al., 1995), which is located about $50 \mathrm{~km}$ west of Moscow and within the general burning region (symbols

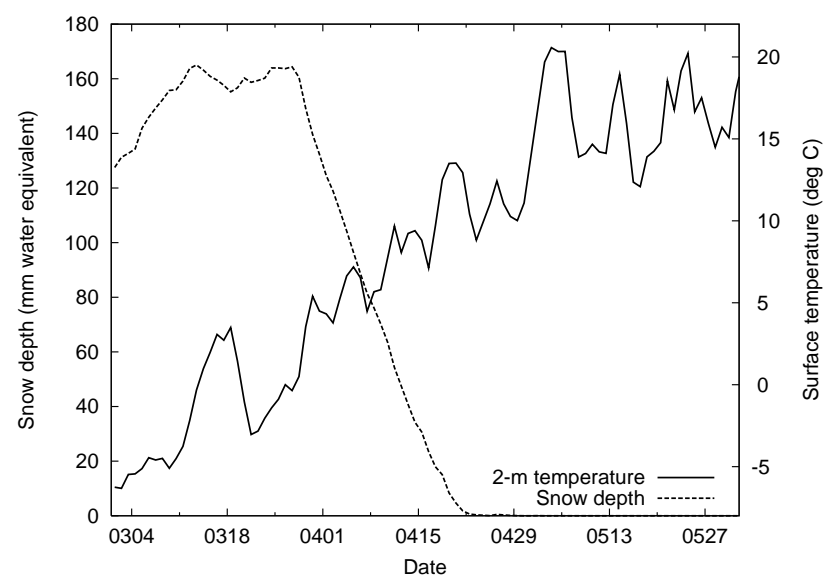

Fig. 4. Time series of snow depth (in mm water equivalent) and air temperature at $2 \mathrm{~m}$ at 12:00 UTC (early afternoon local time) taken from the ECMWF operational analyses and averaged over the region $28-50^{\circ} \mathrm{E}$ and $50-60^{\circ} \mathrm{N}$, for the period from 1 April to 1 June 2006.

in Fig. 3). Superimposed on the seasonal decrease from winter to summer, there is a pronounced peak of total column CO at about the time of the maximum fire occurrence. In other years, the $\mathrm{CO}$ variability was smaller and no late spring maximum was observed.

Following Seiler and Crutzen (1980), BB CO emissions can be estimated using the equation

$E=A B \alpha \beta$

where $A$ is the area burned, $B$ is the biomass per area, $\alpha$ is the fraction of the biomass consumed by the fire, and $\beta$ is the $\mathrm{CO}$ emission factor. Every detected fire was linked to a certain land cover type, using a global land cover classification with a resolution of $1 \mathrm{~km}$ (Hansen et al., 2000). Figure 5 shows a map of the MODIS fire detections between 21 April and 5 May as a function of land cover. The percentage of fires detected, the factors $B, \alpha$ and $\beta$ used for the emission calculation, and the estimated emissions are reported in Table 1 for the various land cover types. The values of $B$ and $\alpha$ are similar to those recently used by Wiedinmyer et al. (2006); values of $\beta$ were taken from Andreae and Merlet (2001). The majority (55\%) of the fires were detected in cropland, $24 \%$ in wooded grassland, $8 \%$ in woodland, $7 \%$ in grassland, and $5 \%$ in forests. Because of the low fuel loading in cropland, emissions there were only $21 \%$ of the total, whereas wooded grassland contributed $36 \%$, woodland $12 \%$, grassland $4 \%$, and forests $26 \%$.

It must be cautioned that our emission estimates are highly uncertain. We estimate that the total area burned is uncertain by at least a factor of two. We furthermore expect the attribution of fires to land cover types other than croplands to be biased high. In a pixel with a mosaic of different land cover types including croplands, a detected fire is most likely burn- 
Table 1. Percentage of deteced fires, factors used for the emission calculations, and estimated CO emissions for the different land cover classes from the Hansen et al. (2000) inventory. Only fires detected in the region north of $40^{\circ} \mathrm{N}$ and between 20 and $60^{\circ} \mathrm{E}$, and during the period 21 April and 5 May, were considered here. Percentage values were normalized to the total number of detected fires, 7749, and the estimated total biomass burning emission, 1.6 Tg CO.

\begin{tabular}{llccccc}
\hline $\begin{array}{l}\text { Land cover } \\
\text { number }\end{array}$ & $\begin{array}{l}\text { Land cover } \\
\text { type }\end{array}$ & $\begin{array}{c}\text { detections } \\
(\%)\end{array}$ & $\begin{array}{c}B \\
{\left[\mathrm{~kg} \mathrm{~m}^{-2}\right]}\end{array}$ & $\alpha$ & $\beta$ & $\begin{array}{c}\text { emissions } \\
(\%)\end{array}$ \\
\hline 1 & Evergreen Needleleaf Forest & 1.2 & 14 & 0.4 & 0.107 & 6.8 \\
4 & Deciduous Broadleaf Forest & 0.3 & 14 & 0.4 & 0.107 & 1.9 \\
5 & Mixed Forest & 3.1 & 14 & 0.4 & 0.107 & 17.4 \\
6 & Woodland & 7.9 & 4 & 0.5 & 0.080 & 11.8 \\
7 & Wooded Grassland & 24.2 & 4 & 0.5 & 0.080 & 36.2 \\
8 & Closed Shrubland & 0.2 & 4 & 0.5 & 0.080 & 0.3 \\
9 & Open Shrubland & 0.0 & 4 & 0.5 & 0.080 & 0.1 \\
10 & Grassland & 7.5 & 1 & 0.9 & 0.065 & 4.1 \\
11 & Cropland & 55.0 & 0.5 & 0.9 & 0.092 & 21.3 \\
13 & Urban and Built-up & 0.5 & 0.1 & 0.9 & 0.070 & 0.0 \\
\hline
\end{tabular}

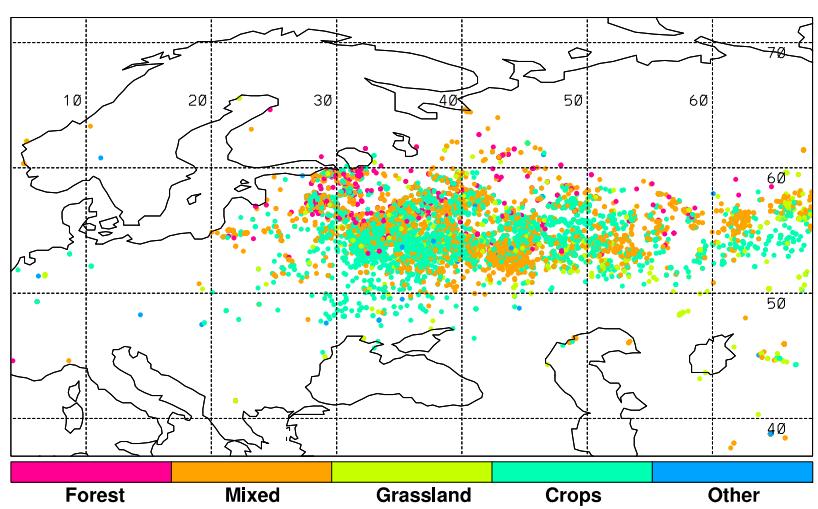

Fig. 5. MODIS fire detections between 21 April and 5 May 2006. The color indicates the dominant land cover where the detection occurred. Land cover classes 1, 4 and 5 from Table 1 were combined into "Forest", classes 6-9 into "Mixed".

ing on agricultural fields, since the fires were started by farmers. Our algorithm, however, attributes it to the dominant land cover type. Assuming that all fires actually burned on agricultural fields would lead to $60 \%$ lower total emissions. Additional uncertainties are associated with the factors $B, \alpha$ and $\beta$, such that the overall uncertainty of the $\mathrm{BB}$ emission estimate is at least a factor of three.

In addition to the $\mathrm{BB}$ emissions, we also used $\mathrm{CO}$ emissions from fossil fuel combustion (FFC) sources. For Europe, we used the expert emissions taken from the UNECE/EMEP (United Nations Economic Commission for Europe/Co-operative Programme for Monitoring and Evaluation of Long Range Transmission of Air Pollutants in Europe) emission database for the year 2003. These data are based on official country reports with adjustments made by experts (Vestreng et al., 2005) and are available at $0.5^{\circ}$ resolution from http://www.emep.int. The emissions were uniformly reduced by $10 \%$ to account for a likely reduction of
European CO emissions since 2003. Emissions elsewhere were taken from the EDGAR 3.2 Fast Track 2000 dataset (Olivier et al., 2001). Both datasets also include emissions from biofuel and waste burning, which were added to the FFC emissions.

\section{Model simulations}

Simulations of air pollution transport were made using the Lagrangian particle dispersion model FLEXPART (Stohl et al., 1998; Stohl and Thomson, 1999; Stohl et al., 2005) (see http://zardoz.nilu.no/ andreas/flextra+flexpart. $\mathrm{html})$. FLEXPART was validated with data from continentalscale tracer experiments (Stohl et al., 1998) and was used previously to study the transport of BB emissions to downwind continents (Forster et al., 2001; Damoah et al., 2004) and into the Arctic (Stohl et al., 2006), as well as the transport of FFC emissions between continents (Stohl et al., 2003) and into the Arctic (Eckhardt et al., 2003). FLEXPART is a pure transport model and no removal processes were considered here. The only purpose of the model simulations is to identify the sources of the measured pollution.

FLEXPART was driven with analyses from the European Centre for Medium-Range Weather Forecasts (ECMWF, 2002) with $1^{\circ} \times 1^{\circ}$ resolution (derived from $\mathrm{T} 319$ spectral truncation) and two nests $\left(108^{\circ} \mathrm{W}-27^{\circ} \mathrm{W}, 9^{\circ} \mathrm{N}-54^{\circ} \mathrm{N}\right.$; $27^{\circ} \mathrm{W}-54^{\circ} \mathrm{E}, 35^{\circ} \mathrm{N}-81^{\circ} \mathrm{N}$ ) with $0.36^{\circ} \times 0.36^{\circ}$ resolution (derived from T799 spectral truncation). In addition to the analyses at 00:00, 06:00, 12:00 and 18:00 UTC, 3-hour forecasts at 03:00, 09:00, 15:00 and 21:00 UTC were used. There are 23 ECMWF model levels below $3000 \mathrm{~m}$, and 91 in total. We also made alternative FLEXPART simulations using input data from the National Centers for Environmental Prediction Global Forecast System (GFS) model with $1^{\circ} \times 1^{\circ}$ resolution and 26 pressure levels. 
ECMWF Analysis VT:Wednesday 3 May 2006 00UTC 1000hPa geopotential height
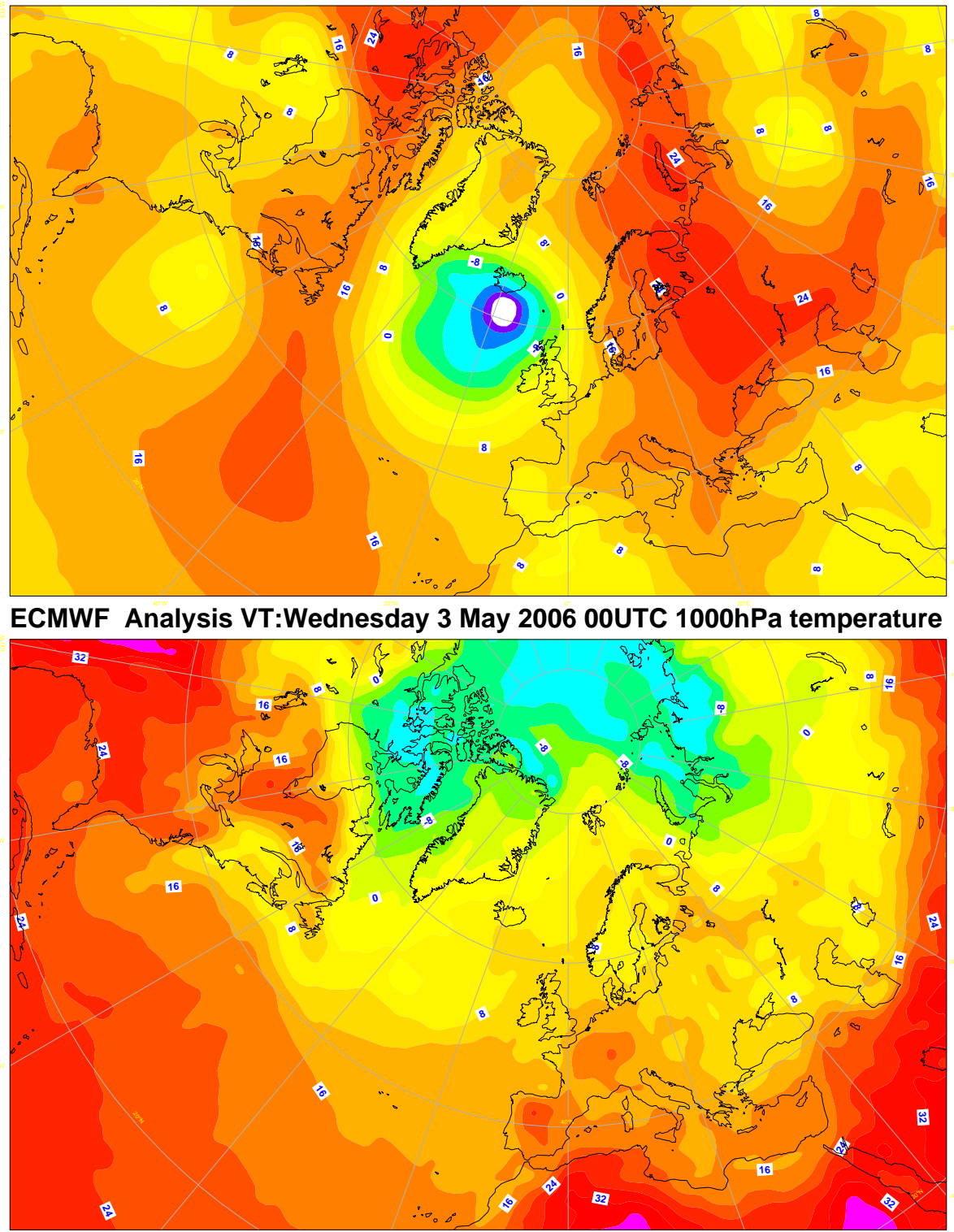

Fig. 6. ECMWF analyses of geopotential (top) and temperature (bottom) at the $1000 \mathrm{hPa}$ level on 3 May 2006 at 00:00 UTC.

FLEXPART calculates the trajectories of so-called tracer particles using the mean winds interpolated from the analysis fields plus random motions representing turbulence. For moist convective transport, FLEXPART uses the scheme of Emanuel and Živković-Rothman (1999), as described and tested by Forster et al. (2006). In order to maintain high accuracy of transport near the poles, FLEXPART advects particles on a polar stereographic projection poleward of $75^{\circ}$ but using the ECMWF winds on the latitude-longitude grid to avoid unnecessary interpolation. A special feature of FLEXPART is the possibility to run it backward in time (Stohl et al., 2003; Seibert and Frank, 2004).
For this study, FLEXPART was run both forward from the emission fields and backward in time from the Zeppelin station. The purpose of the forward simulation was to identify the areas affected by the BB emissions and to understand the transport in relation to the synoptic conditions. 13 million tracer particles of equal mass were released from the fire locations, with the number of particles used depending on a fire's calculated emission strength. The particles were injected between 0 and $100 \mathrm{~m}$ above the surface, as satellite images show that the agricultural fires did not trigger substantial pyro-convection. Forward tracer simulations were also made for FFC CO emissions from Europe, North America and Asia, respectively. Tracer particles were tracked for 
20 days, after which they were removed from the simulation.

Backward simulations from Zeppelin were made for 3hour time intervals in April and May 2006. For each such interval, 40000 particles were released at the measurement point and followed backward in time for 20 days, forming what we call a retroplume, to calculate a potential emission sensitivity (PES) function, as described by Seibert and Frank (2004) and Stohl et al. (2003). The word "potential" indicates that this sensitivity is based on transport alone, ignoring removal processes that would reduce the sensitivity. The value of the PES function (in units of $\mathrm{s} \mathrm{kg}^{-1}$ ) in a particular grid cell is proportional to the particle residence time in that cell. It is a measure for the simulated mixing ratio at the receptor that a source of unit strength $\left(1 \mathrm{~kg} \mathrm{~s}^{-1}\right)$ in the respective grid cell would produce. For consistency with the forward simulations, we report PES values for a so-called footprint layer $0-100 \mathrm{~m}$ above ground. Folding (i.e., multiplying) the PES footprint with the emission flux densities (in units of $\mathrm{kg} \mathrm{m}^{-2} \mathrm{~s}^{-1}$ ) from the FFC and BB inventories yields so-called potential source contribution (PSC) maps, that is the geographical distribution of sources contributing to the simulated mixing ratio at the receptor. Spatial integration finally gives the simulated mixing ratio at the receptor. Time series of these mixing ratios, obtained from the series of backward simulations, will be presented both for FFC and BB emissions. Since the backward model output was generated daily, the timing of the contributing emissions is also known.

\section{Pollution transport to the Arctic}

The meteorological situation in the northern hemisphere in late April and beginning of May was characterized by socalled low-zonal-index conditions with large waves in the middle latitudes, which produced strong undulations of the jet stream and caused effective meridional exchange of air. This can be seen in Fig. 6 (top), which shows the situation on 3 May at 00:00 UTC, approximately at the time with the highest pollution levels measured at Spitsbergen. There were several strong high- and low-pressure centers in the northern hemisphere. The Icelandic low dominated the circulation over the northern North Atlantic and a prominent anticyclone was located over northeastern Europe. This pressure configuration corresponds to a positive phase of the North Atlantic Oscillation pattern, which is known to enhance pollution transport into the Arctic (Eckhardt et al., 2003). Consequently, air from the European continent was channelled into the Arctic between the two pressure centers, leading to abnormally high temperatures over the Norwegian and Barents Seas and the Arctic Ocean (see Fig. 6, bottom). The situation on 25-27 April (not shown) was similar. Indeed, the first pulse of smoke arrived at Spitsbergen already on 27 April. Between the two episodes, the Icelandic low moved further north and interrupting the northward flow for two days. This also brought some precipitation to Svalbard on 28 and 29 April (4 and $9 \mathrm{~mm}$ at Ny Ålesund). After 3 May, the anticyclone over Eastern Europe grew and extended further to the west. On 7 May, it stretched into the Norwegian Sea, such that air from Europe was first transported westward to the British Isles, and then around the high and to the north. Still later, the high's center moved to Greenland, and the European outflow reached Iceland but not anymore Svalbard. While no precipitation was measured on Svalbard during the first days of May, the episode was ended by a cold front bringing rain and snow $(1,4$ and $7 \mathrm{~mm}$ precipitation at Ny Ålesund on 6, 7, and 8 May) and finally clean Arctic air masses to the archipelago (Meteorological Institute, 2006).

The synoptic situation is somewhat reminiscent of the conditions when Arctic Haze is observed at Svalbard in winter and early spring (Iversen, 1984; Iversen and Joranger, 1985). However, instead of the pollution source region being extremely cold as it occurs during Arctic Haze, the Arctic receptor region became unusually warm in spring 2006. Should the warming of the Arctic continue to proceed more quickly than that of the middle latitudes, such transport conditions may become more frequent in the future.

To illustrate the transport of the smoke from the fires in Eastern Europe, we show maps of the total column BB CO tracer from the FLEXPART forward simulation, with superimposed MODIS AOD values, for the period 29 April-7 May (Fig. 7). AOD isolines are not closed where retrievals were not successful over snow-covered parts of Scandinavia, Arctic ice, and near clouds. We also compare the model results to CO retrievals from AIRS (Fig. 8). On 29 April (Fig. 7a), the plume stretched from the fire region where maximum AOD values were about 1.3 units, northwestward to Scandinavia. The close correspondence between the FLEXPART passive tracer simulation and the MODIS AOD field suggests that aerosols were not removed from the atmosphere to a significant extent, and that the aerosol distribution over Europe was dominated by the BB emissions. CO retrievals from AIRS (Fig. 8a) also show the highest values over the fire region but weaker spatial gradients.

One day later, on 30 April (Fig. 7b and 8b), the pollution plume reached the Norwegian Sea, and on 2 May (Fig. 7c and 8c), it had already arrived at Svalbard. AOD retrievals were not successful around Svalbard but values up to 1.5 units can be found a few degrees east of it (Fig. 7c). On 2 May, this plume is also the most prominent feature in the AIRS map (Fig. 8c). The retrieved CO enhancement over the Norwegian Sea (roughly $200 \mathrm{mg} \mathrm{m}^{-2}$ above the background of about $1000 \mathrm{mg} \mathrm{m}^{-2}$ ) compares well with the FLEXPART $\mathrm{BB} \mathrm{CO}$ tracer values in this region.

On 3 May, both the FLEXPART BB CO and AIRS CO show a dramatic increase over Eastern Europe, following the peak in the number of fire detections on 2 May. The roughly $400 \mathrm{mg} \mathrm{m}^{-2} \mathrm{CO}$ enhancement above the background seen by AIRS again agrees well with the FLEXPART BB CO in the fire region. The plume was still present around Spitsbergen 
a) 29 April 2006

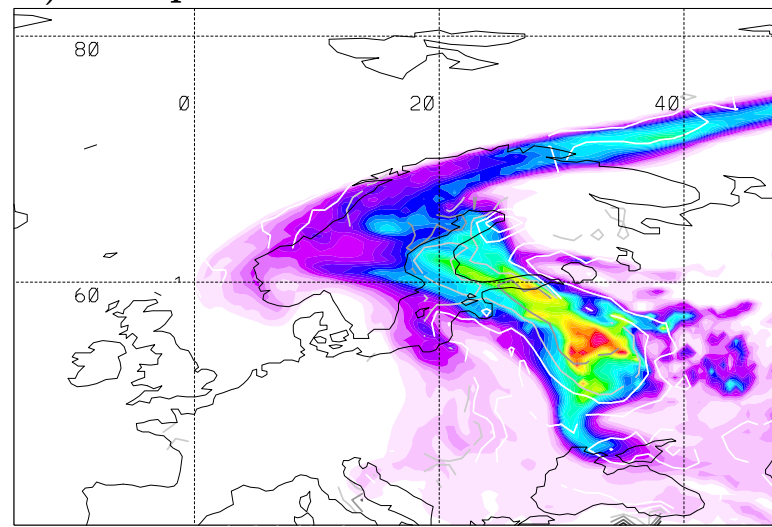

c) 2 May 2006

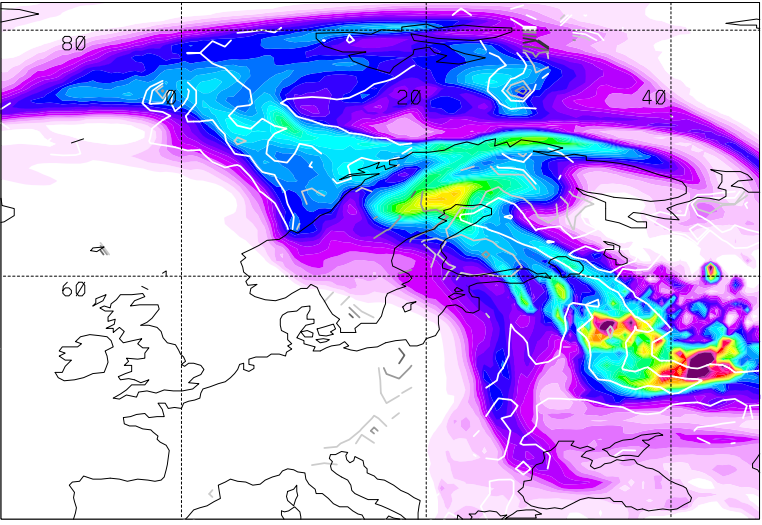

e) 5 May 2006

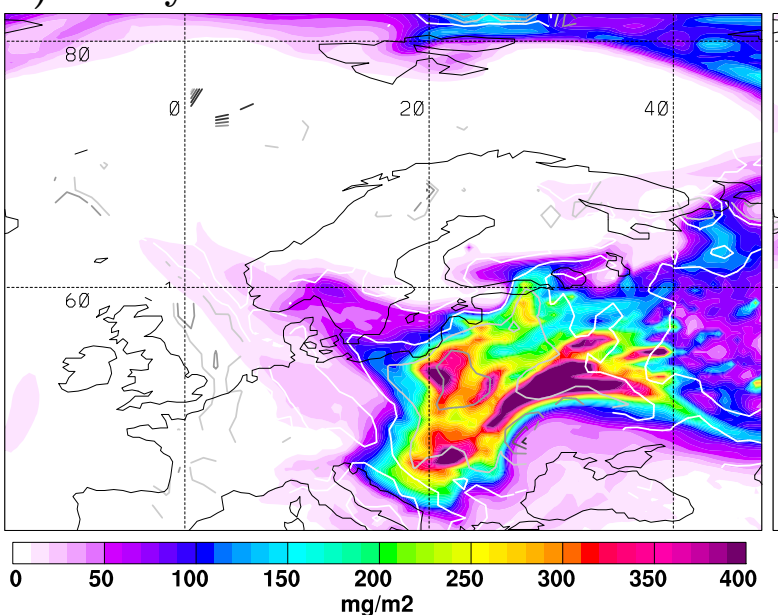

b) 30 April 2006

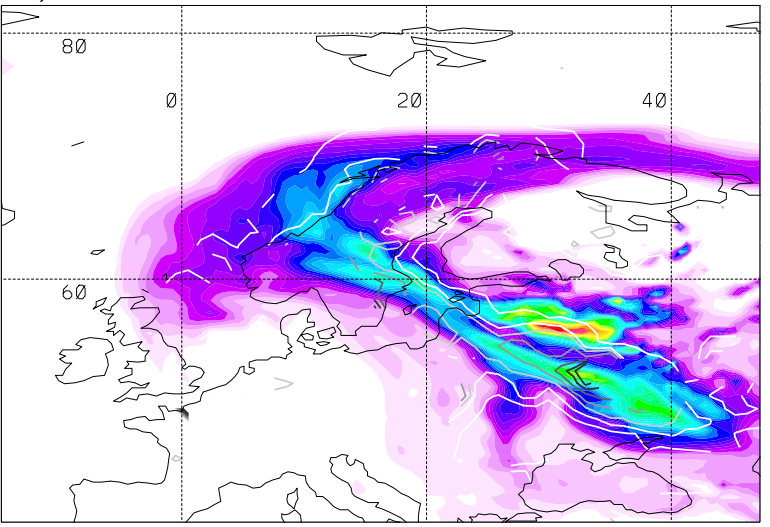

d) 3 May 2006

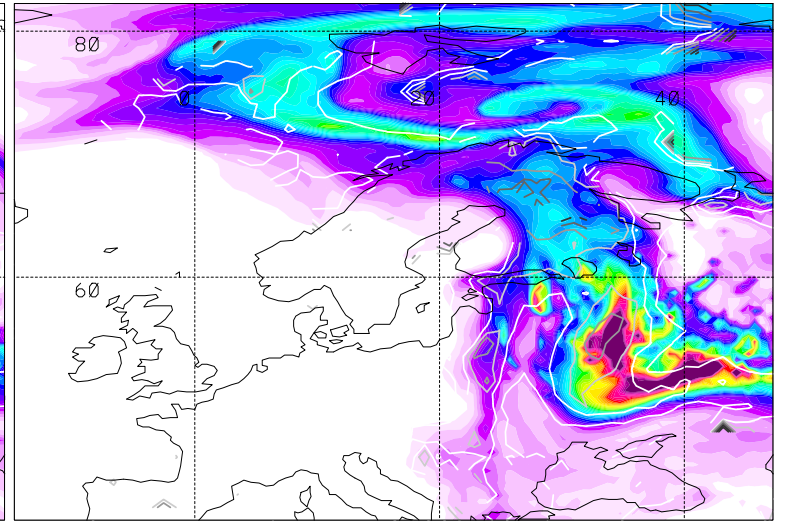

f) 7 May 2006

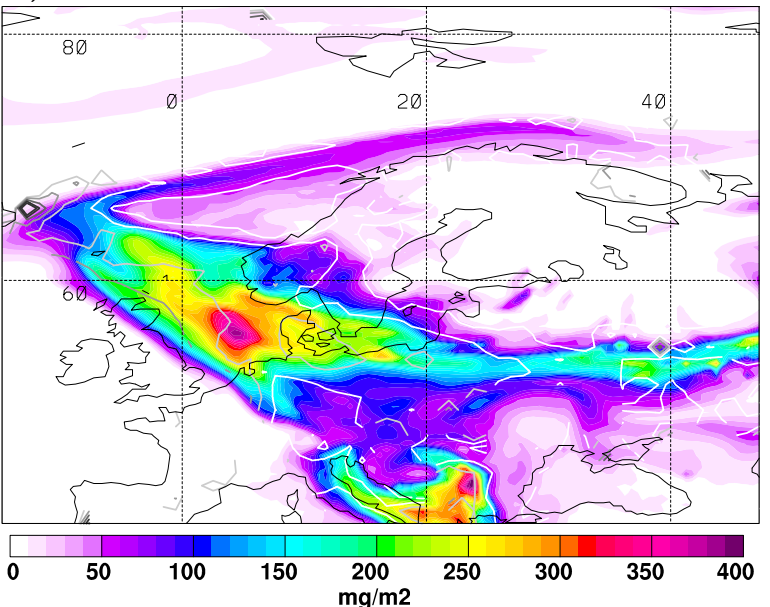

Fig. 7. Total columns of the FLEXPART biomass burning CO tracer at 09:00-12:00 UTC for (a) 29 April, (b) 30 April, (c) 2 May, (d) 3 May, (e) 5 May, and (f) 7 May 2006. Superimposed on the CO tracer maps are the 0.3, 0.5, 0.7, 1.0, 1.5, and 2 unit isolines (shown in white to dark gray) of the daily MODIS Terra Level-3 AOD product.

on 3 (Fig. 7d and 8d) and 4 May but then moved further to the northeast and was replaced by somewhat cleaner air on 5 and 6 May. On 5 May (Fig. 7e), a band of high AOD values (up to about 0.8 units) extended northwestwards from the British
Isles. This band is not associated with BB CO tracer but can be seen in the FFC CO tracer simulation (not shown) and, thus, can be attributed to the export of pollution from Western Europe. AOD maxima also occur southwest of Spitsbergen 
a) 29 April 2006

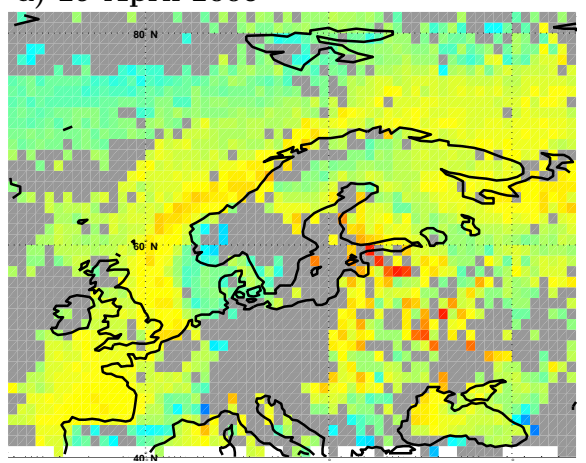

c) 2 May 2006

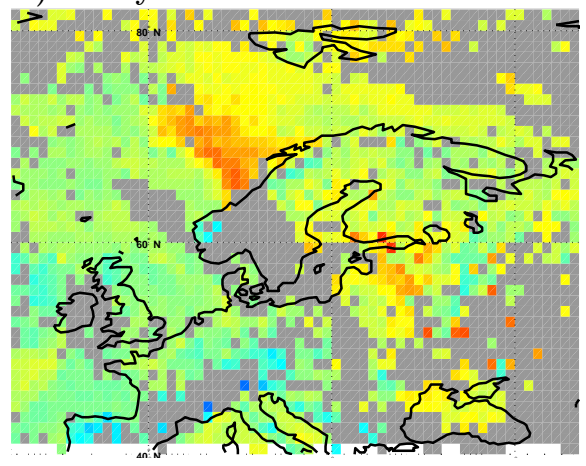

e) 5 May 2006
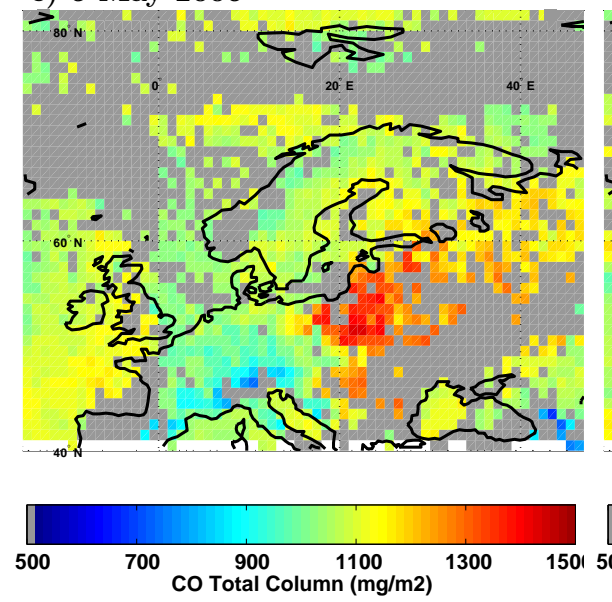

b) 30 April 2006

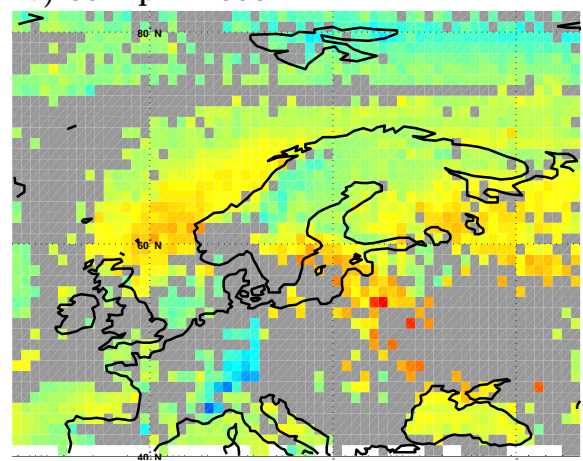

d) 3 May 2006

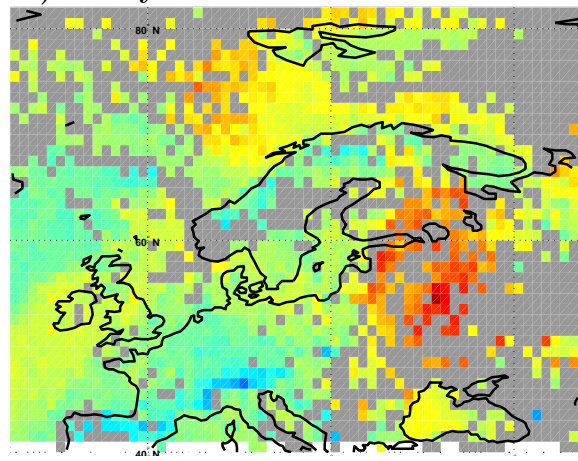

f) 7 May 2006
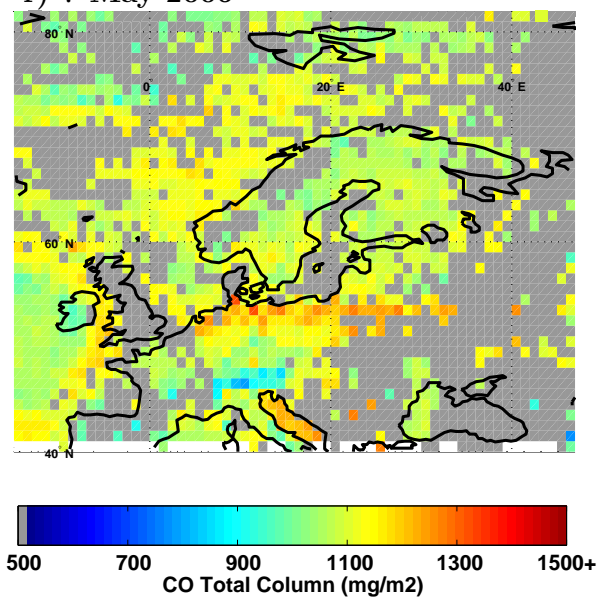

Fig. 8. Total CO columns retrieved from AIRS data for (a) 29 April, (b) 30 April, (c) 2 May, (d) 3 May, (e) 5 May, and (f) 7 May 2006.

(near $0^{\circ} \mathrm{W}$ and $75^{\circ} \mathrm{N}$ ) where the FFC plume arrived on 6 May.

On 7 May (Fig. 7f), the BB plume was exported into the North Atlantic and arrived at Iceland on 8 May (not shown). This part of the plume did not reach Spitsbergen anymore where a change in wind direction replaced the polluted warm air with clean Arctic air (see the temperature drop in Fig. 1). Relatively high CO columns are still seen by AIRS over the Norwegian and Barents Sea on 5-7 May (Fig. 8e-f), which FLEXPART attributes mostly to FFC in Europe (not shown; but see Fig. 10, explained later).
Figure 9 shows PES footprints of the retroplumes from the Zeppelin station for two 3-hour intervals, 27 April 18:0021:00 UTC and 2 May 21:00-24:00 UTC, during the two main observed pollution episodes. Fire detection locations are superimposed on the PES footprint maps in regions where and only for days on which the daily PES footprint value exceeds $0.005 \mathrm{~ns} \mathrm{~kg}^{-1}$ (nanoseconds per kilogram). For 27 April (Fig. 9a), the retroplume travels northward from Eastern Europe and converges towards the station from the east. The high PES footprint values (yellowish colors) extend into the area where many fires were detected when the 
air passed over it 3-4 days before its arrival at Zeppelin. For 2 May 21:00-24:00 UTC (Fig. 9b), the retroplume is more narrow and, in fact, the PES maps for 2, 3, and 4 May are all similar, with the retroplumes coming from Eastern Europe and passing over Scandinavia. The air traveled over many fires 2-5 days before arriving at Zeppelin and picked up copious amounts of BB emissions. The air was also contaminated with FFC emissions, mostly from around Moscow according to the PSC map (not shown). However, the total FFC CO is only $10 \mathrm{ppb}$, much less than the simulated BB $\mathrm{CO}$ of $72 \mathrm{ppb}$ and the observed $\mathrm{CO}$ enhancement of about $100 \mathrm{ppb}$.

Figure 10 shows time series of the simulated $\mathrm{CO}$ tracer mixing ratios from all backward simulations between 24 April and 9 May. Simulated CO tracers are shown for BB (Fig. 10a) and FFC (Fig. 10b), BB+FFC (Fig. 10c), and $\mathrm{BB}+\mathrm{FFC}$ obtained when using the alternative GFS analyses for driving FLEXPART (Fig. 10d). In all panels, the observed $\mathrm{CO}$ is shown as a black line. The previously highest 2-hour mean $\mathrm{CO}$ mixing ratio measured at the station since the year 2001 of $230 \mathrm{ppb}$ was exceeded on 2 and 3 May. Since simulated CO tracers accumulated emissions only over 20 days, they do not reproduce the observed $\mathrm{CO}$ background of about $140 \mathrm{ppb}$. However, the episodes of elevated $\mathrm{CO}$ are well captured by the sum of $\mathrm{BB}$ and FFC CO tracers. There are subtle differences between the two simulations using ECMWF and GFS data (e.g., the GFS simulation overestimates the $\mathrm{CO}$ peak on 27 April, whereas the ECMWF simulation overestimates the largely anthropogenic $\mathrm{CO}$ peak on 7 May) but generally both model versions reproduce the observed $\mathrm{CO}$ variations reasonably well. Both show a first pollution episode on 27 April, then a break, a strong episode from 1-5 May, followed by cleaner periods and weaker episodes on 6 and 7 May.

According to both model versions, BB emissions were always mixed with FFC emissions, which is not surprising given that the fires were burning in densely populated areas. There were some periods when FFC emissions dominated, e.g., on 6 and 7 May, but both model versions attribute most of the $\mathrm{CO}$ enhancement during the main episode from 1-5 May to BB. However, it is important to keep in mind that the relative contributions of $\mathrm{FFC}$ and $\mathrm{BB}$ emissions can be very different for species other than $\mathrm{CO}$.

According to FLEXPART, the BB plume was traveling at altitudes below $3 \mathrm{~km}$ at all times. This is confirmed by plots of the corrected normalized relative backscatter signal from the micropulse lidar at Ny Ålesund (Fig. 11), which shows strong returns mostly below $2 \mathrm{~km}$. On 2 May and on 3 May in the morning, when the highest pollution levels were measured at Zeppelin, the smoke aerosol concentrations decreased with altitude and the station was in the densest part of the plume. However, on 3 May in the afternoon, the smoke was more dense aloft. This is captured by the FLEXPART BB CO tracer simulation and also confirmed by an ozonesonde launched from Ny Ålesund on 3 May, which a) 27 April 2006, 18-21 UTC

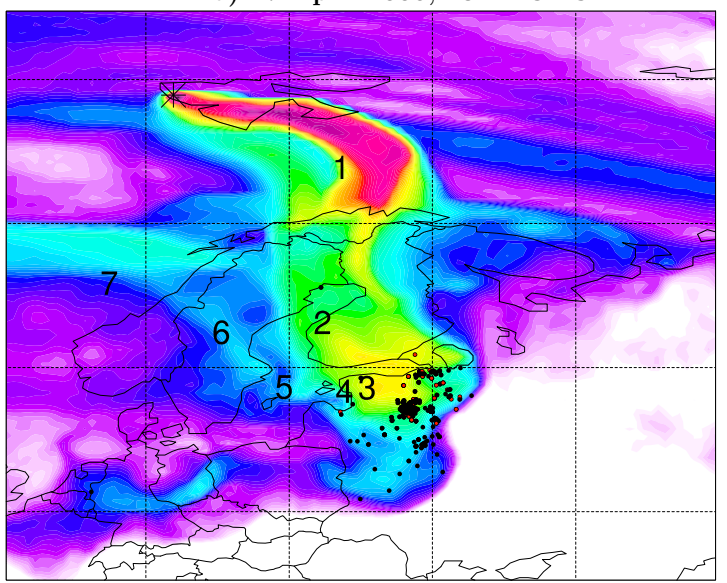

b) 2 May 2006, 21-24 UTC

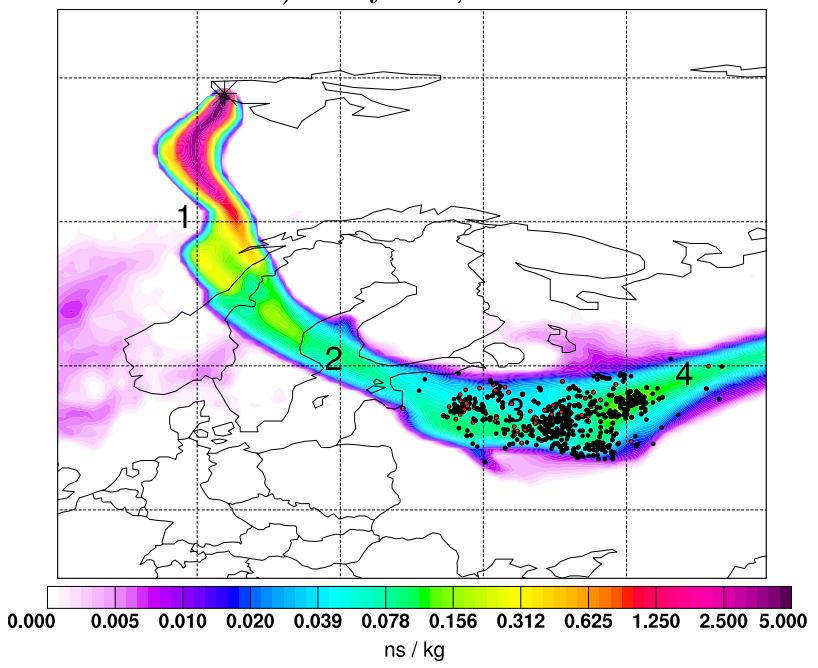

Fig. 9. Potential emission sensitivity (PES) footprint maps for air arriving at Zeppelin on 27 April 2006, between 18:00 and 21:00 UTC (top), and for air arriving at Zeppelin on 2 May 2006, between 21:00 and 24:00 UTC (bottom). Black dots show MODIS fire detections on days when the footprint emission sensitivity in the corresponding grid cell on that day exceeded $0.005 \mathrm{~ns} \mathrm{~kg}^{-1}$. If a fire detection occurred in a pixel with forest as the main land cover type, a smaller red dot is superimposed. Numbers close to the main retroplume pathway label the plume centroid position at daily intervals.

shows increasing $\mathrm{O}_{3}$ mixing ratios up to $2 \mathrm{~km}$ and a decrease at about $2.4 \mathrm{~km}$ (see Fig. 15, discussed later). On average, the smoke observed at Ny Ålesund had a layer thickness of about $2 \mathrm{~km}$ and, thus, filled a significant part of the troposphere.

\section{Air chemistry and aerosol observations}

\subsection{Halocarbons}

The hydrofluorocarbons HFC-134a and HFC-152a (atmospheric lifetimes of 14 and 1.4 years, respectively) are used 


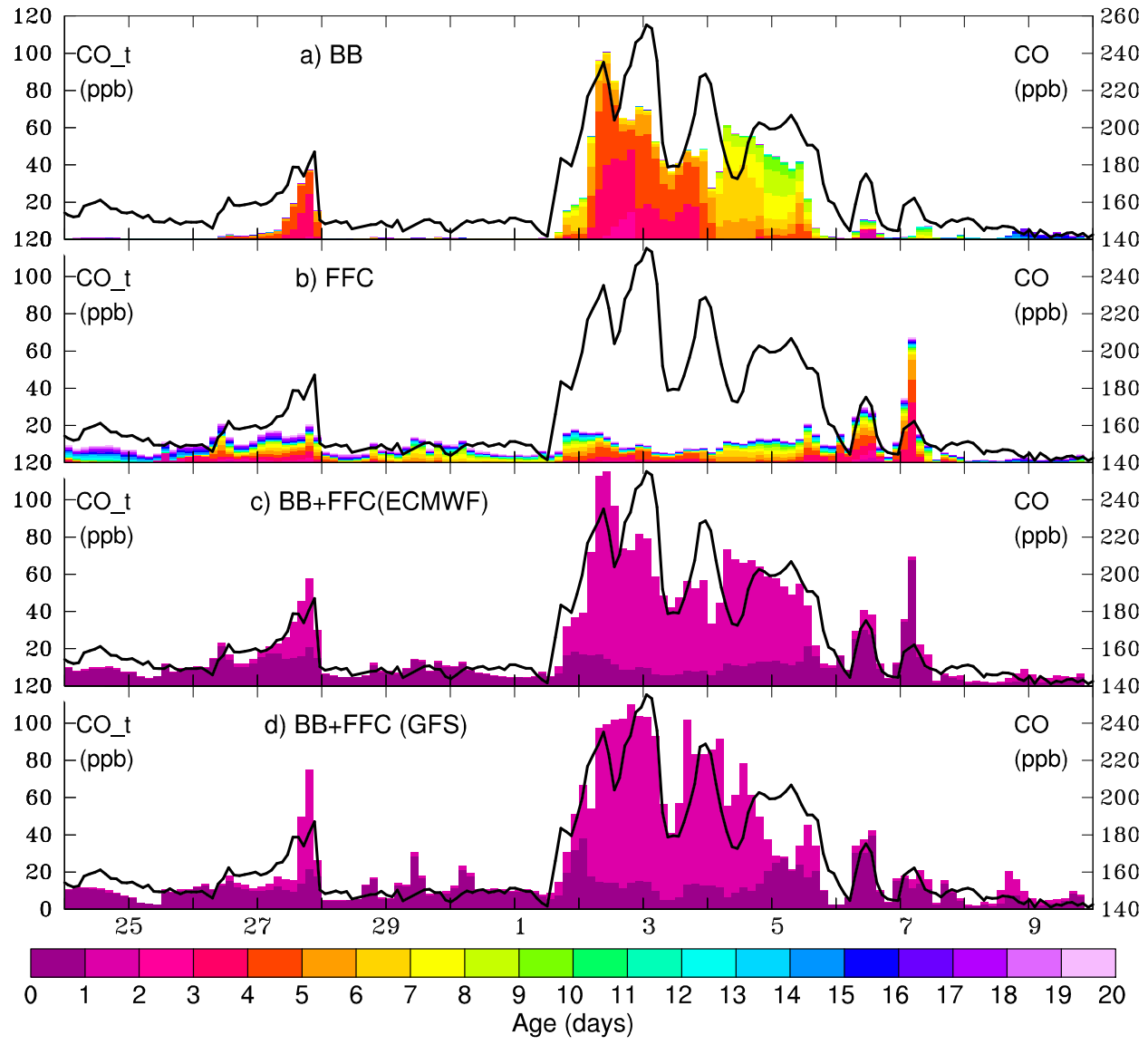

Fig. 10. Comparison of time series of modeled $\mathrm{CO}$ tracers from the backward simulations (colored bars, referring to left axes) with measured $\mathrm{CO}$ (black lines, referring to right axes) at Zeppelin. Measured $\mathrm{CO}$ is shown in every panel, whereas the colored bars are (a) biomass burning (BB) CO tracer, (b) fossil fuel combustion (FFC) CO tracer, (c) BB+FFC CO tracer, (d) BB+FFC CO tracer. Model results shown in panels $(\mathrm{a}-\mathrm{c})$ were produced by driving FLEXPART with ECMWF analyses, whereas those shown in panel (d) were produced with GFS data. The colors in (a) and (b) give the age (i.e., time since emission) of the CO tracers according to the label bar, whereas in (c) and (d) the colors separate FFC (darker color) and BB CO (lighter color).
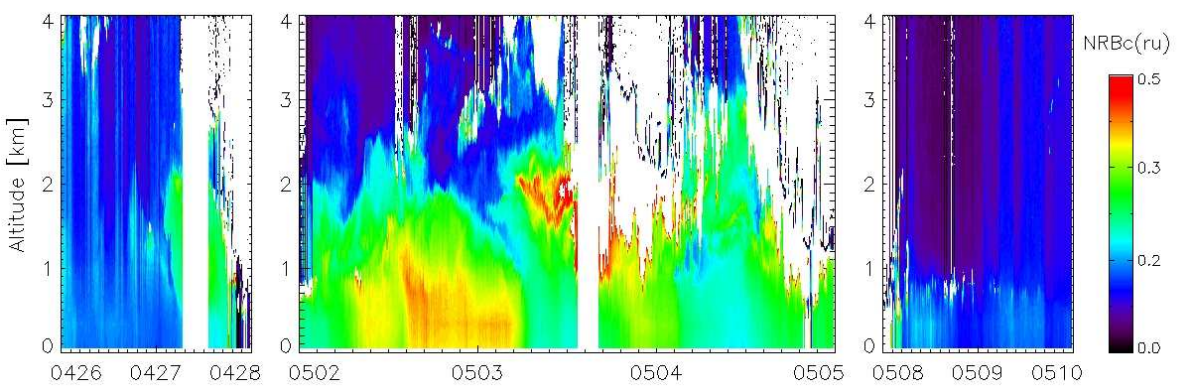

Fig. 11. Normalized relative backscatter (NRB), corrected for Rayleigh contribution, from the micropulse lidar located at Ny Ålesund measured during the period 26 April to 9 May 2006. White areas correspond to missing data. Two periods (28 April-1 May, 5-7 May) are not shown because of poor data coverage due to the presence of clouds.

as refrigerants and blowing agents for producing insolation foams (WMO, 2005). Since they have no natural sources, they are excellent tracers for emissions from anthropogenic activities. At remote observatories, distinct peaks of HFC- 134a and HFC-152a concentrations occur when air masses from major population centers are transported to the station (Reimann et al., 2004). Even though HFC-134a and HFC152a are not themselves emitted by FFC, their regional emis- 


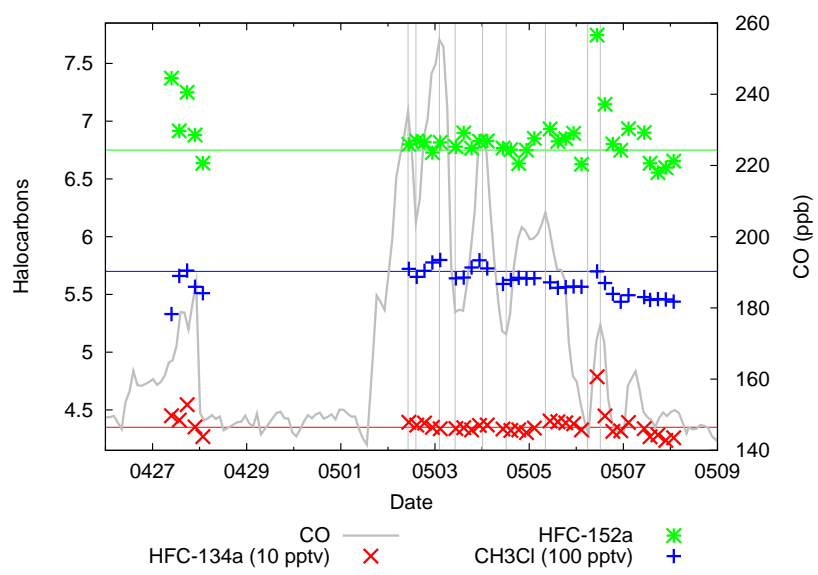

Fig. 12. Time series of measured CO, HFC-152a, HFC-134a, and $\mathrm{CH}_{3} \mathrm{Cl}$ measured at Zeppelin from 26 April to 9 May 2006. Horizontal lines, as well as vertical lines through local $\mathrm{CO}$ maximum and minimum values are drawn for better guidance.

sion patterns correlate with those of FFC, such that they can help identifying when pollution levels are influenced by FFC emissions. In contrast, methyl chloride $\left(\mathrm{CH}_{3} \mathrm{Cl}\right)$ has mostly natural sources, including BB (Khalil and Rasmussen, 1999, 2003).

Figure 12 shows HFC-134a, HFC-152a, and $\mathrm{CH}_{3} \mathrm{Cl}$ measurements superimposed on the time series of measured $\mathrm{CO}$. Instrument maintenance work was performed at the end of April/beginning of May, such that the data record is unfortunately not complete but still sufficient for our purpose. The anthropogenic tracers HFC-134a and HFC-152a both have their highest values on 27 April and 6 May, at times when FLEXPART suggests relatively strong FFC episodes (see Fig. 10). The enhancements during the main $\mathrm{CO}$ episode from 1-5 May are much smaller. HFC-134a values are higher at the beginning (2 May) and at the end (5 May) of this period than in its middle (3-4 May), in agreement with the FLEXPART FFC CO tracer concentrations (Fig. 10). On the other hand, $\mathrm{CH}_{3} \mathrm{Cl}$ is well correlated with $\mathrm{CO}$ in the $\mathrm{BB}$ plume. The peak enhancement above the background on 3 May of about 30 pptv corresponds to an enhancement ratio (ER) of 0.0003 , relative to the $100 \mathrm{ppb} \mathrm{CO}$ enhancement. This is consistent with reported $\mathrm{CH}_{3} \mathrm{Cl} / \mathrm{CO}$ emission ratios from vegetation fires (Andreae and Merlet, 2001). In summary, this confirms that at Zeppelin $\mathrm{CO}$ was dominated by $\mathrm{BB}$ emissions, whereas FFC emissions played a smaller role.

\subsection{Carbon dioxide}

Figure 13 compares time series of $\mathrm{CO}_{2}$ and $\mathrm{CO}$. The two species co-variate from 24 April-5 May but are anticorrelated later on. The likely reason for the anti-correlation during the FFC episodes on 6 and 7 May is that the source regions for these episodes are in Western Europe where the

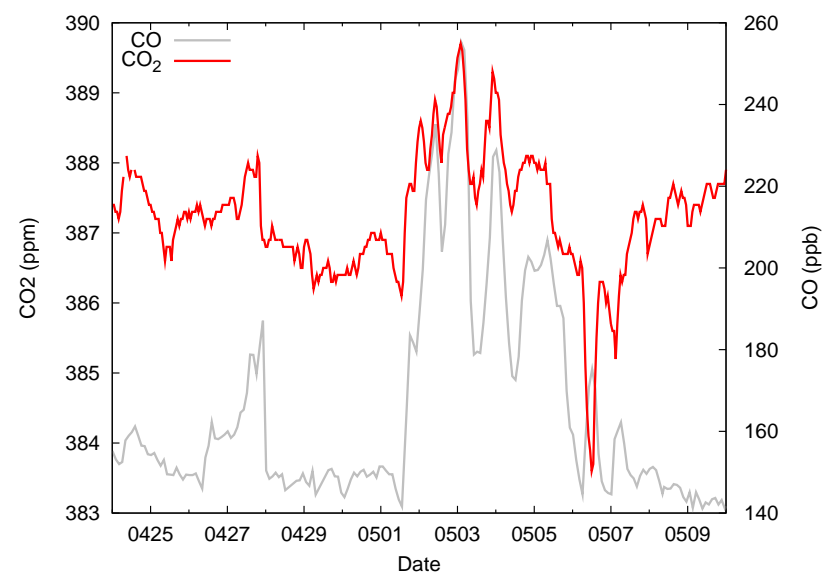

Fig. 13. Time series of $\mathrm{CO}_{2}$ and $\mathrm{CO}$ measured at Zeppelin from 24 April to 10 May 2006.

vegetation was already active and took up more $\mathrm{CO}_{2}$ than what was emitted by FFC. However, during the major BB episode, $\mathrm{CO}$ and $\mathrm{CO}_{2}$ are highly correlated, thus facilitating a regression analysis. Since CO data were available as twohour means with irregular starting times, every $\mathrm{CO}$ value was assigned the 1-hourly $\mathrm{CO}_{2}$ value that fell entirely into the $\mathrm{CO}$ sampling interval. Standard linear regression analysis with $\mathrm{CO}_{2}$ as the independent variable resulted in a $\mathrm{CO} / \mathrm{CO}_{2}$ slope of 0.023 (after conversion to mass mixing ratios) and a Pearson correlation coefficient of 0.91 for the period 1-4 May. In comparison, average $\mathrm{CO} / \mathrm{CO}_{2}$ emission ratios from passenger cars range from 0.002-0.016 (Vasic and Weilenmann, 2006) and, according to the EDGAR inventory, Germany's overall $\mathrm{CO} / \mathrm{CO}_{2}$ emission ratio in the year 2000 was about 0.006. Agricultural fires have a much higher $\mathrm{CO} / \mathrm{CO}_{2}$ emission ratio of 0.06 with an uncertainty of a factor of two (Andreae and Merlet, 2001). Assuming $\mathrm{CO} / \mathrm{CO}_{2}$ emission ratios of 0.006 and 0.06 for FFC and $\mathrm{BB}$ emissions, respectively, the observed $\mathrm{CO} / \mathrm{CO}_{2}$ slope of 0.023 indicates that $35 \%$ of the $\mathrm{CO}_{2}$ and $82 \%$ of the $\mathrm{CO}$ variability during 1-4 May were due to $\mathrm{BB}$.

\subsection{Ozone}

The peak $\mathrm{O}_{3}$ mixing ratios during both episodes clearly exceeded the previously set long-term (since 1989) record-high 1-hour-mean mixing ratio of $61 \mathrm{ppb}$ at the Zeppelin station and set a new record of 83 ppb (Fig. 14). An ozonesonde launched on 3 May at 11:00 UTC measured increasing $\mathrm{O}_{3}$ mixing ratios with altitude up to some $2400 \mathrm{~m}$ asl, above which $\mathrm{O}_{3}$ decreased sharply at a temperature inversion that capped the polluted layer (Fig. 15).

In order to explore whether the extremely high $\mathrm{O}_{3}$ levels were due only to the high loads of precursor substances or also to especially effective $\mathrm{O}_{3}$ formation, we performed standard linear regression analyses with measured $\mathrm{CO}$ as the 


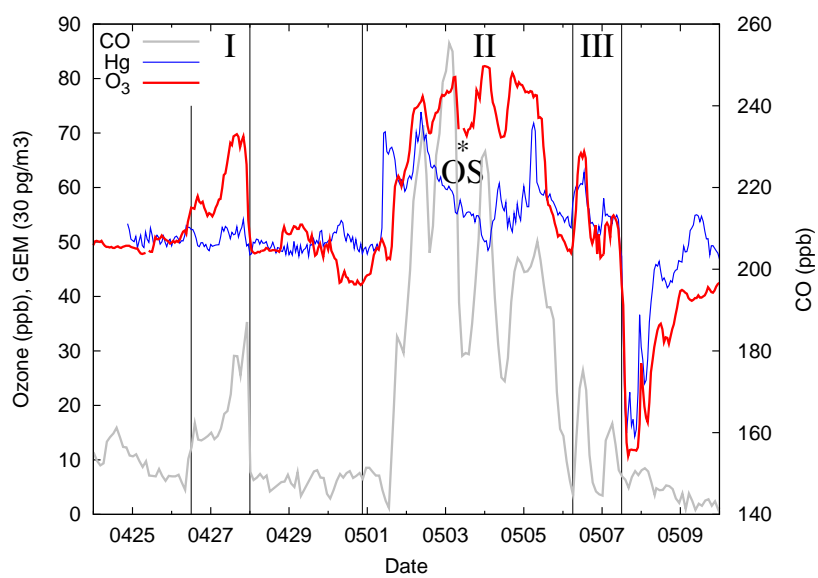

Fig. 14. Time series of $\mathrm{CO}, \mathrm{O}_{3}$, and GEM measured at Zeppelin from 24 April to 10 May 2006. Vertical lines mark the duration of periods "I", "II" and "III", respectively. The asterisk labelled "OS" indicates the launch time of an ozonesonde from Ny Ålesund.

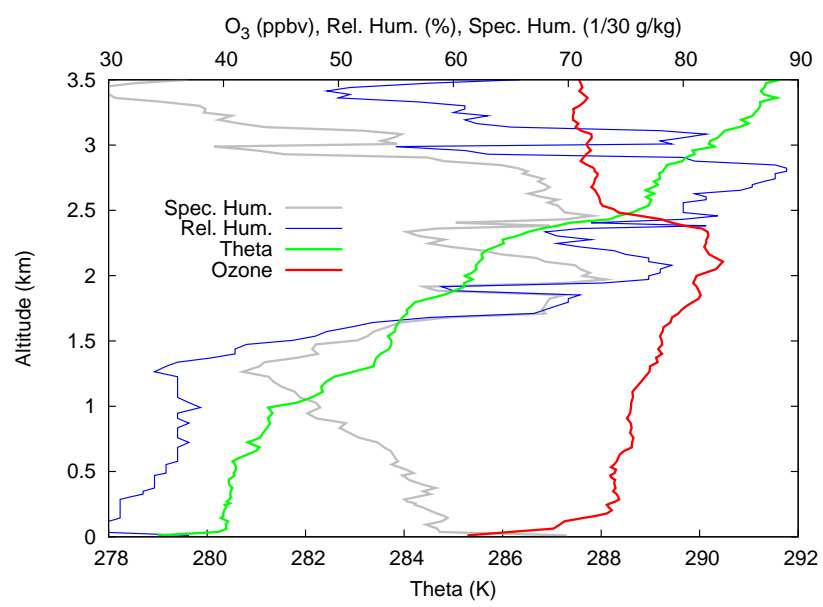

Fig. 15. Vertical profiles of specific humidity, relative humidity, potential temperature (Theta), and $\mathrm{O}_{3}$ obtained from an ozonesonde launched at 11:00 UTC on 3 May from Ny Ålesund.

independent variable, for the three periods marked in Fig. 14, and for the remaining April-May data. As described before for $\mathrm{CO}_{2}$, every 2-hourly $\mathrm{CO}$ value was assigned a 1 hourly $\mathrm{O}_{3}$ value. Figure 16 shows a scatter plot of $\mathrm{O}_{3}$ versus $\mathrm{CO}$ data for the different time periods, with regression lines drawn through the data, and Table 2 reports the regression parameters. Overall, there is a positive $\mathrm{O}_{3}-\mathrm{CO}$ correlation in April-May 2006, which is indicative of a regime dominated by photochemical $\mathrm{O}_{3}$ formation. Note that a negative $\mathrm{O}_{3}-\mathrm{CO}$ correlation would be expected for air masses originating in the stratosphere but stratospheric air masses cannot normally descend into the Arctic polar dome (Stohl, 2006). Pearson correlation coefficients for the three periods range from 0.84 0.87 , indicating compact positive $\mathrm{O}_{3}-\mathrm{CO}$ relationships.
Table 2. Analyses of the correlations between $\mathrm{CO}$ and $\mathrm{O}_{3}$ at Zeppelin for different periods as defined in Fig. 14. Shown are the number of data points $(N)$, the Pearson correlation coefficient $(r)$, the slope, and the intercept of the regression line. For the second period, calculations were also performed separately for $\mathrm{CO} \leq 200 \mathrm{ppb}$, and $\mathrm{CO}>200 \mathrm{ppb}$, respectively.

\begin{tabular}{lcccr}
\hline Period & $N$ & $r$ & slope & intercept \\
\hline Period I & 19 & 0.87 & 0.53 & $-26.7 \mathrm{ppb}$ \\
Period II & 64 & 0.84 & 0.34 & $1.6 \mathrm{ppb}$ \\
Period II, CO $\leq 200 \mathrm{ppb}$ & 39 & 0.85 & 0.51 & $-28.3 \mathrm{ppb}$ \\
Period II, CO $>200 \mathrm{ppb}$ & 25 & 0.23 & 0.04 & $67.6 \mathrm{ppb}$ \\
Period III & 15 & 0.87 & 0.58 & $-36.2 \mathrm{ppb}$ \\
Rest of April-May & 614 & 0.61 & 0.42 & $-22.6 \mathrm{ppb}$ \\
\hline
\end{tabular}

The slopes of the $\mathrm{O}_{3}-\mathrm{CO}$ regression lines are of particular interest, since they inform about the number of $\mathrm{O}_{3}$ molecules formed per $\mathrm{CO}$ molecule emitted, assuming that both $\mathrm{CO}$ and $\mathrm{O}_{3}$ are conserved during transport. For aged North American FFC plumes in the North Atlantic region in summer, Parrish et al. (1998) reported average $\mathrm{O}_{3}$-CO slopes of $0.25-0.40$, with values up to 1.0 for individual plumes. For the Azores, an average slope of 1.0 was reported for summer conditions (Honrath et al., 2004). For aged BB plumes, $\mathrm{O}_{3}$-CO slopes are normally less steep, which is due to the lower $\mathrm{NO}_{\mathrm{x}} / \mathrm{CO}$ emission ratios of $\mathrm{BB}$ compared to FFC and, thus, less efficient $\mathrm{O}_{3}$ formation per $\mathrm{CO}$ molecule. Over Alaska, Wofsy et al. (1992) found average $\mathrm{O}_{3}$-CO slopes of 0.1 in BB plumes; downwind of North American boreal forest fires, Real et al. (2006) reported small negative to small positive values; Wotawa and Trainer (2000) found small positive slopes of $0.05-0.11$ in BB plumes transported from Canada to the eastern United States; for the Azores, Honrath et al. (2004) reported a range of 0.4-0.9 for plumes from boreal forest fires (with contributions from FFC); and Andreae et al. (1994) reported slopes of $0.46 \pm 0.23$ for BB plumes over the tropical South Atlantic.

The $\mathrm{O}_{3}$-CO slope of 0.42 found for our data set for the non-episode periods in April-May (Table 2) lies between the slopes of 0.25-0.40 reported by Parrish et al. (1998) and 1.0 by Honrath et al. (2004) for FFC combustion plumes in summer. The slopes for BB period I (0.53) and (mostly) FFC combustion period III (0.58) are large compared to previously reported values, indicating highly efficient $\mathrm{O}_{3}$ formation. The slope for BB period II is lower (0.34) but this is a result of a curvature in the $\mathrm{O}_{3}-\mathrm{CO}$ correlation. Separate regression analyses for $\mathrm{CO}$ mixing ratios below $200 \mathrm{ppb} \mathrm{CO}$ (slope of 0.51 ) and above $200 \mathrm{ppb} \mathrm{CO}$ (slope of 0.04) indicate that for the lower $\mathrm{CO}$ mixing ratios, the slope is similar to $\mathrm{BB}$ period I. The lack of correlation between $\mathrm{O}_{3}$ and $\mathrm{CO}$ at the higher $\mathrm{CO}$ levels indicates less efficient $\mathrm{O}_{3}$ formation in those air masses that have received the largest $\mathrm{CO}$ (and likely also $\mathrm{NO}_{\mathrm{x}}$ ) input. In addition, model calculations by 


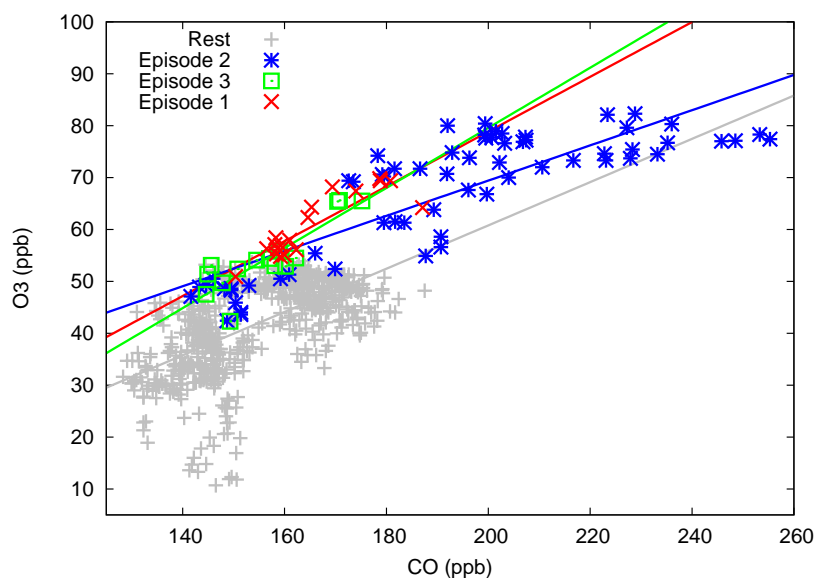

Fig. 16. Scatter plot of $\mathrm{O}_{3}$ versus $\mathrm{CO}$ data from Zeppelin. The data points are colored according to the three periods defined in Fig. 14, and the rest of the data for April-May 2006 is shown in grey. Regression lines through the various data sets are also shown in corresponding colors.

Real et al. (2006) showed that the strong aerosol light extinction in dense $\mathrm{BB}$ smoke plumes can decrease $\mathrm{O}_{3}$ formation efficiency.

Despite the decrease in $\mathrm{O}_{3}$ formation efficiency at the highest $\mathrm{CO}$ levels, the $\mathrm{O}_{3}-\mathrm{CO}$ slopes are higher than most values reported in the literature for BB plumes. This is difficult to explain since these events took place at high latitudes and early in the year. Photolysis rates for these air masses were certainly not optimal for ozone production. Further, preliminary model simulations with the EMEP MSC-W model (Simpson et al., 2003) have failed to simulate the observed ozone increase, despite predicting reasonable values of $\mathrm{CO}$, sulphate and nitrate. It is therefore not entirely clear why the $\mathrm{O}_{3}$-CO slopes are so large, and further model simulations will be needed to quantify the underlying processes. However, several factors could have enhanced the $\mathrm{O}_{3}$ formation: Firstly, FFC emissions of $\mathrm{NO}_{\mathrm{x}}$ were not negligible and were mixed into the BB plumes, which would have shifted the $\mathrm{O}_{3}-\mathrm{CO}$ slope towards the higher values typical for FFC plumes. Furthermore, the agricultural areas in Eastern Europe receive large nitrogen loads from fertilization but also from atmospheric deposition. $\mathrm{NO}_{\mathrm{x}}$ emissions from the fires can be unusually high in such conditions (Hegg et al., 1987), and microbial $\mathrm{NO}_{\mathrm{x}}$ emissions from the soils (Stohl et al., 1996) may have been significant, too. Secondly, no clouds were present and the plumes crossed snow-covered regions whose high albedo enhanced the available radiation. Thirdly, a stable stratification of the polluted air mass is likely along most of the trajectory, as the warm air from continental Europe passes over the snow-covered regions of northern Europe and the relatively cold Atlantic (see, e.g., Fig. 15 for conditions at Ny Ålesund). This stable stratification, as well as the nature of the surface, would ensure very low deposition

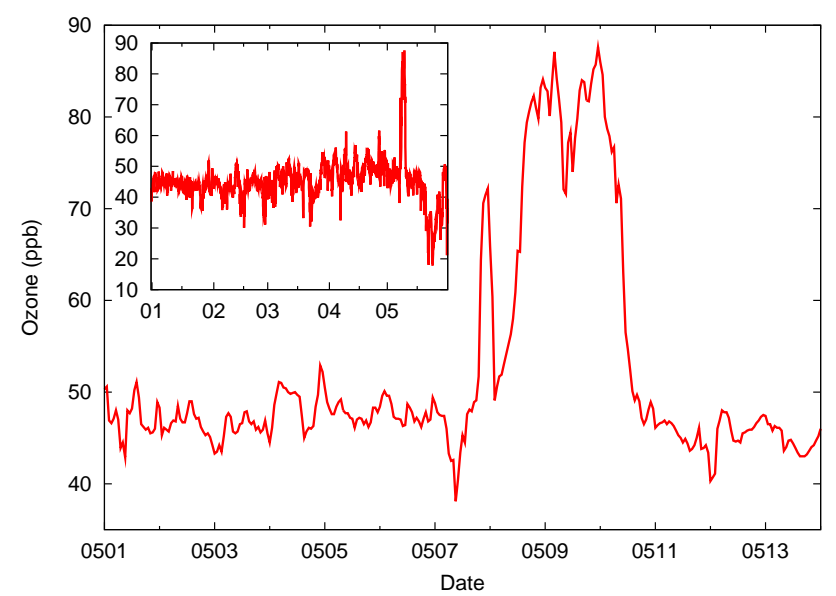

Fig. 17. Time series of $\mathrm{O}_{3}$ measured at Storhofdi on Westman Islands, Iceland, for the period 1 to 13 May. The inset shows the $\mathrm{O}_{3}$ time series for the first five months of the year 2006. The event clearly stands out from the normally rather constant background.

of ozone and other gases over a large fraction of the transport distance. Fourthly, due to the delayed onset of spring in Europe, the vegetation was still dormant, which might have also reduced the dry deposition of $\mathrm{O}_{3}$.

High $\mathrm{O}_{3}$ concentrations similar to those measured at Zeppelin were monitored at several other stations in northern Scandinavia, as the smoke plume was transported across (not shown). Figure $7 \mathrm{f}$ shows that the plume also approached Iceland on 7 May. One day later it arrived at the measurement site at Storhofdi and produced strongly elevated $\mathrm{O}_{3}$ values for about three days (Fig. 17). Normally, $\mathrm{O}_{3}$ at Storhofdi is rather constant at between 40 and $50 \mathrm{ppb}$ in winter and spring (see inset in Fig. 17) and $30 \mathrm{ppb}$ in summer. In fact, in the past $\mathrm{O}_{3}$ levels have exceeded $70 \mathrm{ppb}$ only on three other occasions during the periods with available data (1992-1997, 2003 -present). The peak hourly $\mathrm{O}_{3}$ mixing ratio of $88 \mathrm{ppb}$ measured during the smoke event is $13 \mathrm{ppb}$ higher than any previously measured event.

\subsection{Gaseous elemental mercury}

Gaseous elemental mercury (GEM) was elevated but not well correlated with $\mathrm{CO}$ during the BB episodes (Fig. 14). Measurements of GEM in BB plumes are rare but the following ER to $\mathrm{CO}$ have been reported: $0.067 \times 10^{-6} \mathrm{ppb}$ GEM/ppb $\mathrm{CO}$ (Friedli et al., 2003a) for a mixture of conifers, grass and shrubs, $0.204 \times 10^{-6} \mathrm{ppb}$ GEM/ppb CO (Friedli et al., 2003b) for black spruce, $0.21 \times 10^{-6} \mathrm{ppb}$ GEM/ppb CO (Brunke et al., 2001) for fynbos, and $0.086 \times 10^{-6} \mathrm{ppb}$ GEM/ppb CO (Sigler et al., 2003) for black spruce and jack pine. Assuming the highest reported ER of $0.21 \times 10^{-6} \mathrm{ppb}$ GEM/ppb CO, the observed maximum CO enhancement at Zeppelin of $100 \mathrm{ppb}$ would correspond to $182 \mathrm{pg} \mathrm{m}^{-3}$ GEM enhancement. However, observed GEM increased by more than $600 \mathrm{pg} \mathrm{m}^{-3}$. 


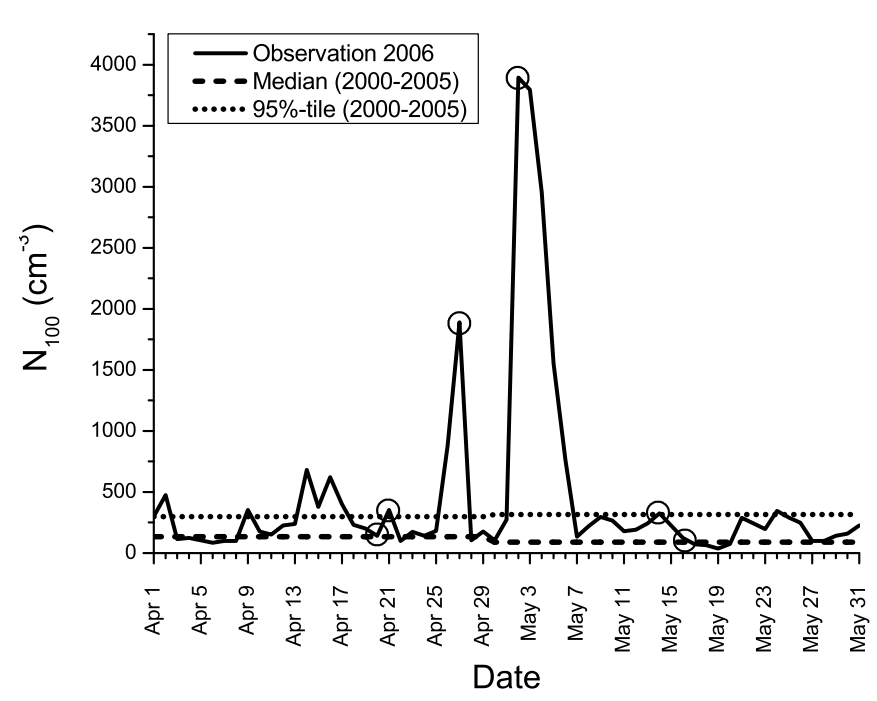

Fig. 18. Time series of the daily mean number concentrations of accumulation mode (100-500 nm diameter) particles at Zeppelin for the period April-May 2006. The horizontal lines show the median and the 95-percentile obtained for the months of April and May in the years 2000-2005. Days for which aerosol size distributions are shown in Fig. 19 are marked with circles.

This, and the lack of correlation with CO suggests that GEM was mostly not coming from BB. Nevertheless, the measured GEM levels are among the highest ever measured during a transport event. Normally, such high levels are reached only during short periods, typically following re-emission of GEM from the ground, after mercury depletion events.

\subsection{Aerosol mass and size distribution}

Regarding the aerosol physical properties, the DMPS measurements revealed that the key characteristic of the BB episodes is the numerous accumulation mode particles. Figure 18 compares the median and 95-percentile of daily mean particle number densities between 100 and $500 \mathrm{~nm}$ diameter calculated for April and May of the years 2000 to 2005 (85\% data coverage) with the observations from 2006. The BB plume events are associated with number concentrations about 10 times larger than the 95-percentile, but the whole period shows a tendency of elevated accumulation mode particles.

To illustrate the enhanced accumulation mode, we have selected six days from just before, during and after the BB episode (marked with circles in Fig. 18). Of these six days, two days represent median accumulation mode number densities, two represent the 95-percentile, and two represent the plume peaks during the events, respectively. Figure 19 compares the aerosol size distributions for these six days. The difference between the pre- and post-episode median and 95-percentile distributions are that the May distributions present a broader accumulation mode and a reminiscence of

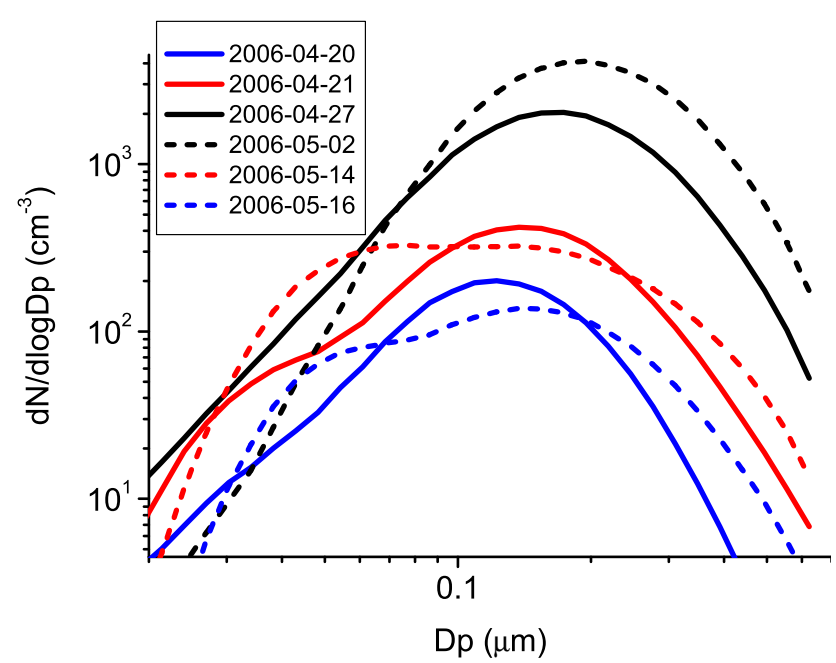

Fig. 19. Aerosol number size distributions measured at Zeppelin on selected days in April and May 2006 as shown in Fig. 18.

an Aitken mode. This is rather typical for the site (Ström et al., 2003) as cloud processing and new particle formation within the Arctic become dominating processes during later May and early June. The plume events are characterized with the complete absence of an Aitken mode, an increase in the number of accumulation mode particles, and a shift towards larger sizes. The later suggests a large increase in particle mass.

Particle mass (PM) concentrations are not measured directly at Zeppelin but they can be estimated from two independent data sets. Firstly, daily means of PM were estimated from the DMPS aerosol number concentration measurements, assuming a density of the aerosols of $1.5 \mathrm{~g} \mathrm{~cm}^{-3}$. Since information on particles larger than $0.7 \mu \mathrm{m}$ was missing, this approach provides a conservative estimate of the PM concentrations encountered during the event. Secondly, we can derive PM from available nephelometer observations (not shown here) using the mean mass scattering coefficient of $1.1 \mathrm{~m}^{2} \mathrm{~g}^{-1}$ reported by Adam et al. (2004) observed in a forest fire plume over the northeastern USA. Since the mass scattering coefficient varies with the type of aerosols encountered, the second approach must be considered highly uncertain. Nevertheless, the resulting two PM data sets are closely correlated with a correlation coefficient above 0.98 , with the nephelometer-based estimates being higher by almost a factor 2. The DMPS approach provided a maximum $24 \mathrm{~h}$ PM concentration of $29 \mathrm{\mu g} \mathrm{m}^{-3}$ during the BB event, which corresponds to an increase by more than an order of magnitude from conditions before and after the episode (Fig. 20). PM concentrations are also closely correlated with $\mathrm{CO}$. 


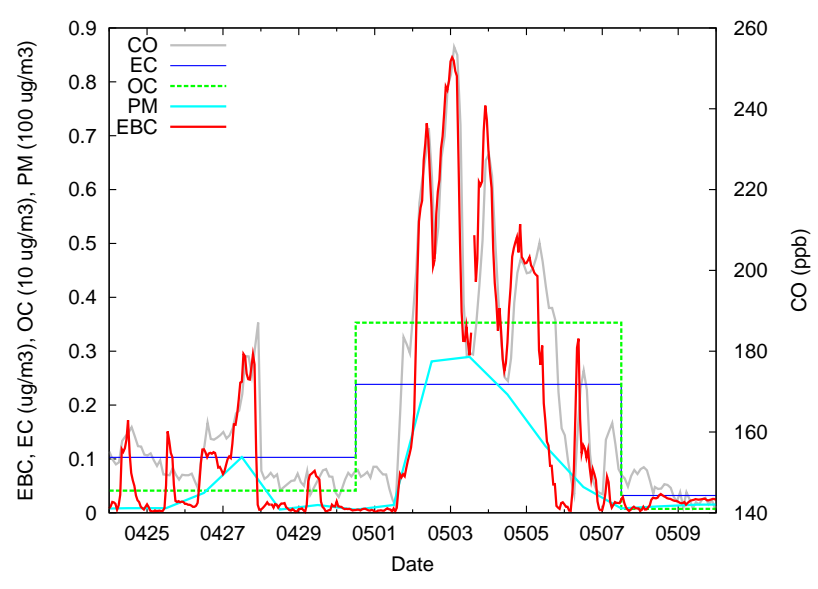

Fig. 20. Time series of equivalent black carbon (EBC) and CO measured at Zeppelin from 24 April to 10 May 2006. Also shown are elemental carbon (EC) and organic carbon (OC) concentrations from weekly samples and daily mean particle mass (PM) concentrations derived from the DMPS data.

\subsection{Carbonaceous material}

The time series of EBC measured with the PSAP and CO are highly correlated, especially during the BB episode (Fig. 20). For period II, as defined in Fig. 14, their correlation coefficient is 0.91 and, after conversion of $\mathrm{CO}$ mixing ratios to concentrations, the $\mathrm{EBC} / \mathrm{CO}$ slope of the regression line is 0.007. This is almost exactly the mean $\mathrm{EBC} / \mathrm{CO}$ emission ratio, 0.0075 , reported for agricultural burning by Andreae and Merlet (2001).

Concentrations of EC and OC (together comprising total carbon, TC) from weekly filter samples are also shown in Fig. 20. There is generally good agreement between the EBC measured with the PSAP and the EC measured with the thermo-optical method. For the sample covering the main BB period from 30 April-7 May, EC and corresponding average EBC concentrations are $0.24 \mu \mathrm{g} \mathrm{m}^{-3}$ and $0.28 \mu \mathrm{g} \mathrm{m}^{-3}$, respectively.

A very low EC/TC ratio of 0.06 was observed during the $\mathrm{BB}$ event, which is considerably lower than what has been reported previously for emissions from burning of agricultural waste (e.g., 0.17 by Andreae and Merlet, 2001). It could be speculated that this is due to condensation of secondary organic material during transport. Furthermore, pollen was observed in the BB plume as it was transported across Scandinavia. If some of this pollen was transported further to Spitsbergen, it would have contributed to the very high OC fraction. For the proceeding weeks of the $\mathrm{BB}$ event, the EC/TC ratio ranged from $0.19-0.39$, indicating contribution from sources more rich in EC.

The EC/EBC concentrations measured during the $\mathrm{BB}$ episode are extremely high for an Arctic station. The highest 1-hour mean EBC concentration measured at Zep-

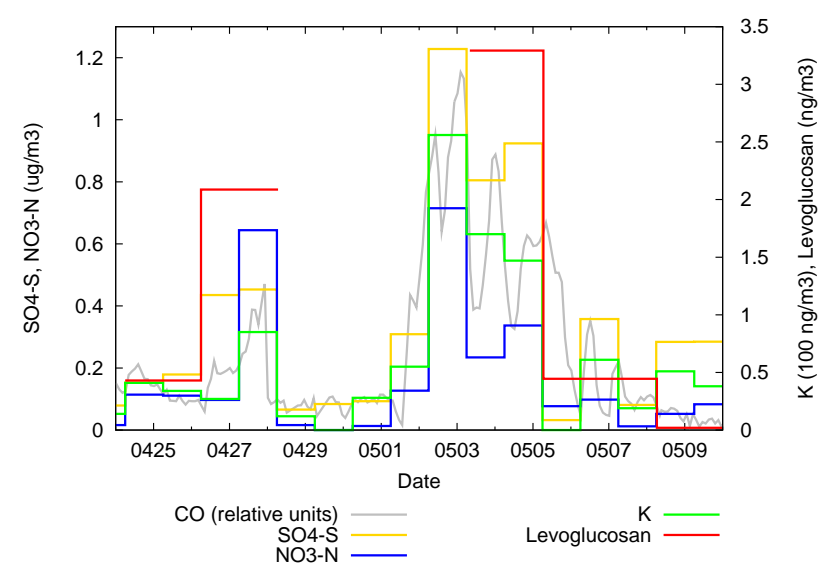

Fig. 21. Time series of $\mathrm{CO}$, and $\mathrm{NO}_{3}^{-}-\mathrm{N}, \mathrm{SO}_{4}^{2-}-\mathrm{S}$ and $\mathrm{K}^{+}$from daily, and levoglucosan from irregular filter samples taken at Zeppelin.

pelin during the period November 2002-August 2005 was $0.28 \mu \mathrm{g} \mathrm{m}^{-3}$, the same value as reported above for the weekly mean and a third of the highest hourly value measured during the BB episode $\left(0.85 \mu \mathrm{g} \mathrm{m}^{-3}\right)$. Thus, the BB episode clearly exceeded any Arctic Haze event observed at Zeppelin in these years. An even higher hourly EBC value of $3.4 \mu \mathrm{g} \mathrm{m}^{-3}$ was measured at Barrow, Alaska when a boreal forest fire plume reached the site (Stohl et al., 2006). However, these fires were burning closer to the station than in our case.

\subsection{Aerosol chemical composition}

Levoglucosan is a specific tracer for BB, which is mostly associated with the fine fraction of aerosols and emitted in sufficiently large quantities to be detectable far away from the fire location (Simoneit et al., 1999). Potassium is another tracer for BB emissions, particularly for those occurring under flaming conditions (Echalar et al., 1995) but is less specific than levoglucosan as it also has other sources. Both levoglucosan and potassium were measured on aerosol filter samples from Zeppelin and both show greatly elevated concentrations during the episodes on 27 April and 1-5 May (Fig. 21). For the highest measured values, the ER values of potassium and levoglucosan relative to $\mathrm{CO}$ were about 0.0026 and 0.000047 , respectively. The potassium/CO ER is in the middle of the range given for the emission ratio by Andreae and Merlet (2001), while the levoglucosan/CO ER is more than an order of magnitude lower than what measured levoglucosan emission factors from agricultural BB (Hays et al., 2005) would suggest. Since aerosols do not seem to have been removed to any significant extent, we suggest that degradation of levoglucosan during transport is a possible reason for the relatively low levoglucosan/CO ER. In a recent laboratory study by Holmes and Petrucci (2006), it was suggested that levoglucosan could be subjected to oligomer- 


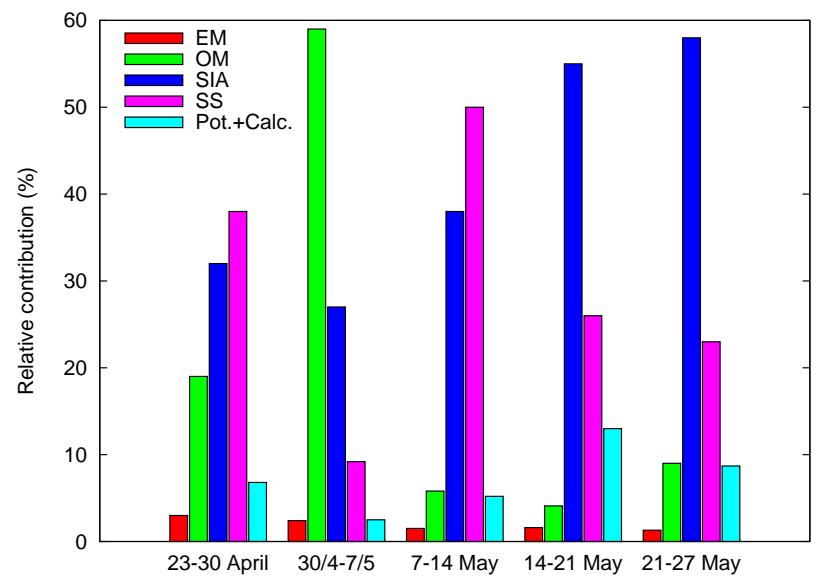

Fig. 22. Relative contributions of different chemical compound classes as defined in the main text, to the total speciated aerosol mass at Zeppelin for the weeks 17-21 of the year 2006.

ization in the atmosphere.

There also exists a long-term record of potassium measurements at Zeppelin. For the years 1993-2003, we found twelve values greater than the highest value measured on 2-3 May $2006\left(0.26 \mu \mathrm{g} \mathrm{m}^{-3}\right)$. Thus, such extreme BB episodes are infrequent at Zeppelin, but occasional episodes may have occurred before.

Sulfate and nitrate were also elevated in the BB plume, reaching $1.2 \mu \mathrm{g} \mathrm{S} \mathrm{m}^{-3}\left(0.12 \mu \mathrm{g} \mathrm{S} \mathrm{m}^{-3}\right.$ of which are attributable to sea salt) and $0.71 \mu \mathrm{g} \mathrm{N} \mathrm{m}^{-3}$, respectively, in the sample taken on 2 May. Again, few ( 8 for sulfate, 11 for nitrate) higher values were found in the long-term (19932003) dataset. In addition, gas-phase $\mathrm{SO}_{2}$ and $\mathrm{HNO}_{3}$ contributed $0.4 \mu \mathrm{g} \mathrm{S} \mathrm{m}^{-3}$ and $0.13 \mu \mathrm{g} \mathrm{N} \mathrm{m}^{-3}$, respectively. Note that while the sum of aerosol nitrate and $\mathrm{HNO}_{3}$ is measured accurately, their separation is uncertain with the employed method. Average FLEXPART FFC source contributions on that day of $1.5 \mu \mathrm{g} \mathrm{S} \mathrm{m}^{-3}$ and $1.1 \mu \mathrm{g} \mathrm{N} \mathrm{m}^{-3}$ suggest that the FFC emissions may suffice for explaining the added gas- and aerosol-phase sulfur and nitrogen concentrations if no removal took place en route. However, FLEXPART predicts several episodes every year with similar or higher FFC source contributions but without observations reaching such high levels, indicating that removal processes are normally more effective than in the $\mathrm{BB}$ plume. Furthermore, using an average emission ratio of $\mathrm{NO}_{\mathrm{x}}-\mathrm{N} / \mathrm{CO}$ of 0.013 for agricultural BB (Andreae and Merlet, 2001) and the observed mean $\mathrm{CO}$ enhancement of about $100 \mu \mathrm{g} \mathrm{m}^{-3}$ would give approximately $1.3 \mu \mathrm{g} \mathrm{N} \mathrm{m}^{-3}$ from $\mathrm{BB}$, more than the FFC contribution. Soil $\mathrm{NO}_{\mathrm{x}}$ emissions may have contributed, too. Reported emission factors for $\mathrm{SO}_{2}$ from $\mathrm{BB}$ are lower but may not be appropriate because the fires burned in a region that received large deposition loads of sulfate from FFC in the past decades (Mylona, 1996). Re-emission of deposited sulfur by fires was recently suggested as an important mech-

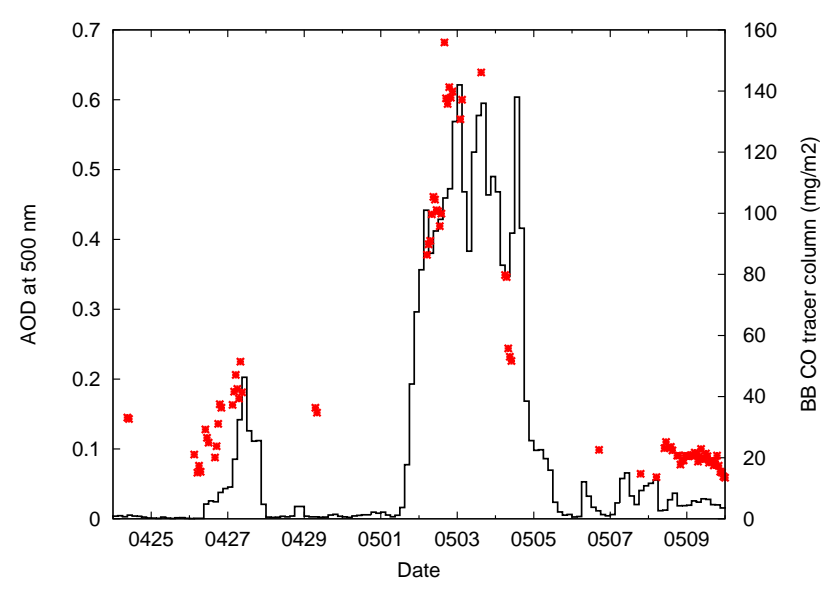

Fig. 23. Time series of aerosol optical depth (AOD) measured at $500 \mathrm{~nm}$ (symbols) and total columns of the FLEXPART biomass burning (BB) CO tracer (line) at Ny Ålesund from 24 April to 10 May 2006.

anism (Langmann and Graf, 2003). Thus, it is quite likely that even for sulfate and nitrate, BB emissions made a significant contribution to measured values on 2-3 May. This would also allow for some deposition to have occurred.

To study how the BB event affected the aerosol chemical composition relative to conditions before and after and to summarize our data, we performed a chemical mass balance calculation. The time resolution of the calculation was limited to one week by the EC/OC data, and since these measurements were started only a week before the event, results for only five weeks are presented. The mass balance comprises contributions of organic matter $(\mathrm{OM}=\mathrm{OC} \times 1.8)$, $\mathrm{EM}(\mathrm{EM}=\mathrm{EC} \times 1.1)$, secondary inorganic aerosols $\left(\mathrm{SIA}=\mathrm{SO}_{4}^{2-}+\mathrm{NO}_{3}^{-}+\mathrm{NH}_{4}^{+}\right)$, sea salt $\left(\mathrm{SS}=\mathrm{Na}^{+}+\mathrm{Cl}^{-}+\mathrm{Mg}^{2+}\right)$, and the sum of $\mathrm{K}^{+}$and $\mathrm{Ca}^{2+}$. The total speciated mass concentrations exceeded the PM concentrations derived from the DMPS measurements by 10$60 \%$, except for the sample from 30 April to 7 May when the DMPS value is higher by about $10 \%$. The fact that the total of the speciated mass concentrations is higher than the DMPS estimate, is to be expected because aerosols greater than $0.7 \mu \mathrm{m}$ are not accounted for in the latter. In Fig. 22, the increased relative contribution of organic matter during the event is striking. While organic matter accounted for $59 \%$ of the sum of the speciated mass during the BB event in the first week of May, the corresponding percentage for the proceeding weeks ranged from 4-9\% only. In contrast, sea salt accounted for only $9 \%$ during the event but between 23 and $50 \%$ in the proceeding weeks.

\subsection{Aerosol optical depth}

Figure 23 compares the AOD at $500 \mathrm{~nm}$ measured at $\mathrm{Ny}$ Ålesund with the total columns of the FLEXPART BB CO 


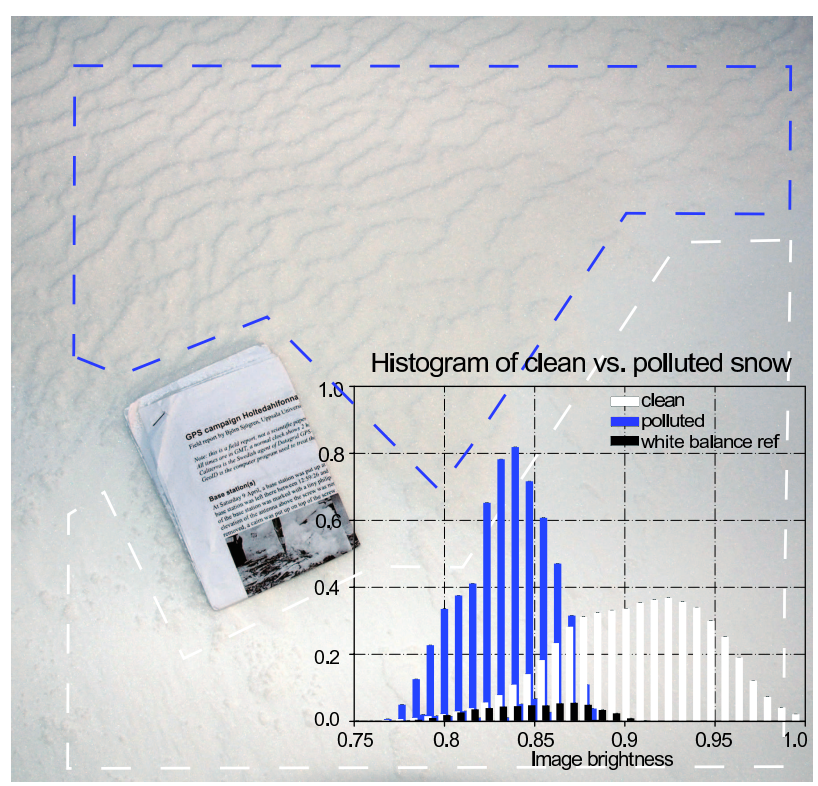

Fig. 24. Photograph from a snow sampling location on the Holtedahlfonna summit. The "polluted" discolored snow is evident on the top half of the figure, while the lower half is representative of the "clean" underlying snow. Areas delineating pixel selection for development of the histograms are outlined in dashed white and blue lines for the "clean" and "polluted" snow, respectively (see text).

tracer above the station. Extreme AOD values were measured during the two episodes on 27 April and 1-5 May. The daily means on 2 and 3 May, respectively, of about 0.5 and 0.6 are the highest values ever measured since the beginning of the measurements in the year 1991. They are approximately a factor of five higher than the long-term mean for the months of April and May. This shows that the smoke strongly perturbed the radiation transmission in the atmosphere, as will be explored further in another study (Treffeisen et al., $2007^{2}$ ).

\section{Aerosol deposition on the snow}

On 3 May 2006, one of the authors (J. F. Burkhart) and several others traveled on snowmobiles from Ny Ålesund about $40 \mathrm{~km}$ east to the summit of the glacier Holtedahlfonna Isbree ( $1179 \mathrm{~m}$ a.s.l.) where they sampled a snowpit to a depth of $2.8 \mathrm{~m}$ and conducted glaciological work. After several hours at the location, the sky noticeable changed color and reddish haze filled the air. This was at about the time with

\footnotetext{
${ }^{2}$ Treffeisen, R., Turnved, P., Ström, J., Herber, A., Bareiss, J., Helbig, A., Stone, R. S., Hoyningen-Hüne, W., Krejci, R., Stohl, A., and Neuber, R.: Arctic smoke - aerosol characteristics during a record air pollution event in the European Arctic and its possible radiative impact, Atmos. Chem. Phys. Discuss., in review, 2007.
}

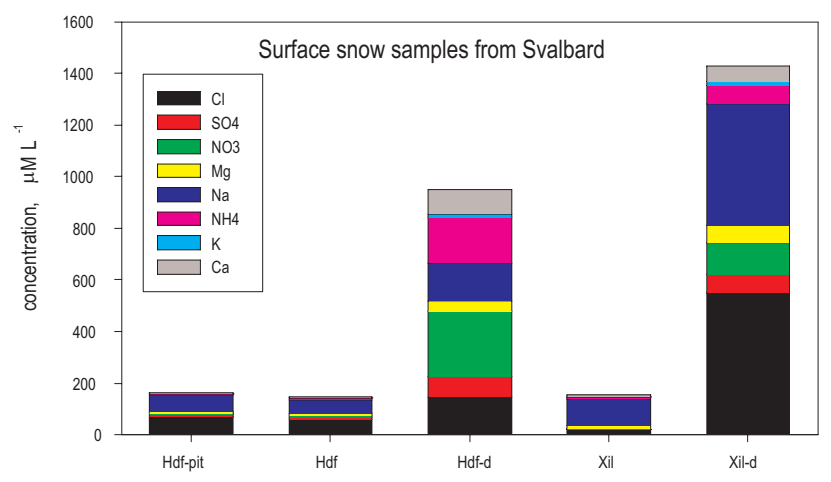

Fig. 25. Holtedahlfonna (Hdf) and Exile Pass (Xil) ion concentrations ("polluted" samples are marked with "-d") in $\mu \mathrm{ML}^{-} 1$. Maximum concentrations from the $2.8 \mathrm{~m}$ pit (covering a period of about 1.5 years) sampled at the summit are also shown for comparison (Hdf-pit).

the largest aerosol backscatter measured by the micropulse lidar at Ny Ålesund for the altitude of around $1200 \mathrm{~m}$ (see Fig. 11). The expedition members began to notice patches of discolored snow around their work area. Returning to the snowmobiles they saw the tracks had filled in with a discolored snow. Winds were out of the southwest and had steadily increased throughout the day to around $7 \mathrm{~m} \mathrm{~s}^{-1}$. There was no snowfall, but the drifted snow was clearly polluted from the event passing overhead. As dry deposition is likely a too slow process to cause the discoloration of the snow within hours, it seems likely that the drifting snow collected aerosols from the atmosphere. Figure 24 is a photograph showing the discolored, accumulated snow on the top half of the image and less affected snow on the bottom. Nine replicate snow samples were collected at two separate locations, one near the Holtedahlfonna (Hdf) summit (Fig. 24) and a second near Exile Pass (Xil) several hundred meters lower in elevation. Pre-cleaned sample bottles were subjectively filled with surface scrapes representing the "polluted" and immediately adjacent "clean" snow. For Hdf, these samples were taken from the areas shown in Fig. 24. Care was taken not to scrape any underlying "clean" snow when collecting the "polluted" snow samples.

To evaluate the extent of pollution in the snow samples and to determine whether the discoloration was caused by dust or the passage of the plume, ion determinations were carried out using a Dionex Dx-120 suppressed ion chromatograph. The anions $\mathrm{Cl}^{-}, \mathrm{NO}_{3}^{-}, \mathrm{SO}_{4}^{2-}$ were determined using Dionex Ionpack AS15 columns. A total of five cations $\left(\mathrm{Na}^{+}, \mathrm{NH}_{4}^{+}, \mathrm{K}^{+}\right.$, $\mathrm{Mg}^{2+}$ and $\mathrm{Ca}^{2+}$ ) were determined using Dionex ICS-1000 suppressed ion chromatograph and Dionex Ionpack CS12 columns. Melted samples were analysed in random order to minimize the effects of any systematic errors. Details of the analytical methods are provided elsewhere (Jauhiainen , 1999; Kekonen, 2002, 2004). 
Figure 25 shows the stacked concentrations of the measured ions. For reference, the snowpit sample with the highest ion load (Hdf-pit), is also shown. $\mathrm{Na}^{+}$and $\mathrm{Cl}^{-}$dominate in the snowpit and "clean" snow samples, indicating a sea salt origin of these ions. Notice that $\mathrm{NO}_{3}^{-}, \mathrm{SO}_{4}^{2-}$ and $\mathrm{NH}_{4}^{+}$concentrations in the "clean" snow are already higher than the highest ones measured in the snowpit, suggesting that even the "clean" snow was contaminated. $\mathrm{Na}^{+}$and $\mathrm{Cl}^{-}$ are elevated in the "polluted" samples, especially in the one from the lower-altitude site (Xil), indicating the deposition of sea salt during the episode, probably related to the high wind speed conditions. However, the most remarkable result is that the concentration levels of $\mathrm{NO}_{3}^{-}, \mathrm{SO}_{4}^{2-}, \mathrm{NH}_{4}^{+}, \mathrm{K}^{+}$and $\mathrm{Ca}^{2+}$ in the "polluted" snow are tens of times higher than in the "clean" and snowpit samples. This comparison provides strong evidence that the source of the discolored snow is transported pollution.

As a cursory investigation into the impact on snow albedo, we resort to the photograph shown in Fig. 24 to evaluate what impact the pollutants may have had on snow reflectivity. The image was first white balanced using the sheet of paper shown. It was then converted to a 16-bit grayscale image. Using a seed filling algorithm (Pavlidis, 1981) and a tolerance of 4 bits, we progressively selected pixels from the "polluted" and "clean" regions of the image until we had representative subsets of each. When selecting pixels in the polluted snow we did not include the shadowed areas resulting from the rippling to avoid biasing the sample downward. The values of the pixels ranged between 0 (black) and 255 (white). By dividing all the values by 255 we define normalized image brightness and calculated histograms of the selected pixels. These histograms are shown in the inset in Fig. 24 for the "polluted", "clean", and reference (white areas of the paper) regions of the image. It is clear that the "polluted" snow had a reduced brightness from the surrounding "clean" snow providing evidence for an albedo effect. Unfortunately, quantitative albedo measurements are not available for the time period. Furthermore, discolored snow patches were frequent but their relative area coverage is not known.

\section{Conclusions}

- A combination of unusually high temperatures in the European Arctic and a pulse of emissions from agricultural fires in the Baltic countries, Belorussia, Ukraine and Russia caused the most severe air pollution episode ever recorded at the Zeppelin research station in Spitsbergen. At the end of April and beginning of May 2006, measured $\mathrm{O}_{3}, \mathrm{CO}$, equivalent black carbon (EBC) concentrations and aerosol optical depths, for which longterm data sets from the Zeppelin station exist, exceeded previously set record values. A new record was also set for the $\mathrm{O}_{3}$ concentrations at a station in Iceland.
- The high temperatures in the Arctic reduced the temperature contrast between the pollution source region and the Arctic, thereby facilitating low-level transport of the pollution into the Arctic. It might be speculated that the continuing disproportionally strong warming of the Arctic climate relative to the midlatitudes could in the future create such conditions more often, thus producing efficient pathways of pollution into the Arctic.

- Due to the late snow melt in Eastern Europe, the agricultural fires were started later than normal, at a time when sunlight was available for the observed strong and highly efficient photochemical production of $\mathrm{O}_{3}$.

- A combination of gas-phase $\left(\mathrm{CO}, \mathrm{CO}_{2}\right.$, halocarbons HFC-134a, HFC-152a, and $\mathrm{CH}_{3} \mathrm{Cl}$ ) and aerosol-phase tracers (levoglucosan and potassium) of biomass burning (BB) and fossil fuel combustion (FFC), as well as calculations with the Lagrangian particle dispersion model FLEXPART, allowed a clear attribution of the observed pollution to BB. FFC emissions contributed little to the $\mathrm{CO}$ enhancement and almost nothing to the aerosol mass but $\mathrm{FFC} \mathrm{NO}_{\mathrm{x}}$ emissions might have been important for $\mathrm{O}_{3}$ formation.

- Enhancement ratios between EBC and CO, as well as between potassium and $\mathrm{CO}$ were similar to reported emission ratios, suggesting that deposition of aerosols was inefficient in this plume. This was likely a result of the stable thermal stratification of the plume which itself may have been produced by stronger heating aloft due to absorption of sunlight by black carbon particles.

- Aerosol size distributions were characterized by the complete absence of an Aitken mode, a strong increase in the number of accumulation mode particles, and a shift of the accumulation mode to larger size, resulting in an increase of particulate mass by more than an order of magnitude relative to unperturbed conditions. The aerosol chemical composition was dominated by organic matter, which accounted for more than $50 \%$ of the speciated aerosol mass.

- A correlation analysis of $\mathrm{O}_{3}$ versus $\mathrm{CO}$ resulted in $\mathrm{O}_{3}$ $\mathrm{CO}$ slopes above 0.5 , which is higher than most values reported in the literature for $\mathrm{BB}$ plumes. This indicates highly efficient $\mathrm{O}_{3}$ formation and little $\mathrm{O}_{3}$ removal. The efficient $\mathrm{O}_{3}$ formation was likely due to an admixture of $\mathrm{NO}_{\mathrm{x}}$ from FFC and soil emissions, but high solar insolation due to clear sky conditions and reflection of sunlight from snow-covered surfaces were probably also important.

- There is photographic evidence that the snow on glaciers at Spitsbergen became discolored during the episode, and we suggest that this was due to the dry deposition of smoke aerosols. In fact, the concentrations 
of potassium, sulfate, nitrate and ammonium ions were tens of times higher in samples of the discolored snow than in snow taken in clean areas and from a snow pit, confirming the deposition of the smoke aerosol. While no albedo measurements were made during the episode, the photographs suggest that the snow albedo was reduced.

- These results and another recent paper (Stohl et al., 2006) suggest that, to date, biomass burning has been underestimated as a source of the Arctic aerosol and trace gases, relative to the more well-known Arctic Haze, which results mostly from fossil fuel combustion and industrial activities.

- Given its large impact on air quality over vast regions and on radiative properties of the atmosphere, banning the practice of agricultural waste burning should be seriously considered.

Acknowledgements. This study was done as part of POLARCAT, an International Polar Year initiative supported by IGAC, iLEAPS, SPARC, and AMAP. We thank A. V. Dzhola and E. I. Grechko for providing the total column $\mathrm{CO}$ data from Zvenigorod, and $\mathrm{L}$. Yurganov for pointing us towards these data. We acknowledge A.C. Engvall for her photographs taken from the Zeppelin station, and O. Brandt and B. Sjögren for photos and field assistance. Thanks to B. Noone and J. Waher for invaluable help with instrumentation and data handling. Ozonesonde data were provided by P. von der Gathen (AWI Potsdam). Thanks are also due to V. Velazco for total column $\mathrm{CO}$ data from Ny Ålesund. We thank the MPLNET staff, J. Campbell and E. J. Welton, for their efforts in establishing and maintaining the site at Ny Ålesund. The NASA Micro-Pulse Lidar Network is funded by the NASA Earth Observing System and Radiation Sciences Program. Thanks also to R. Neuber, who is responsible for all lidar measurements at Ny Ålesund, inclucing the MPL, and K. Marholdt for operating the MPL during the haze event. The global land cover dataset, as well as the MODIS fire detection data were provided by the University of Maryland from their ftp server. NASA provided the MODIS AOD data. Aknowledgments to the funding agencies Swedish Environmental Protection Agency and the Swedish Research Council. Ion chromatographic analyses of aerosol filter samples (preliminary data) have been performed as part of the Norwegian monitoring network of atmosheric deposition, funded by the Norwegian State Pollution Agency.

Edited by: J. Brandt

\section{References}

Adam, M., Pahlow, M., Kovalev, V. A., Ondov, J. M., Parlange, M. B., and Nair, N.: Aerosol optical characterization by nephelometer and lidar: The Baltimore Supersite experiment during the Canadian forest fire smoke intrusion, J. Geophys. Res., 109, D16S02, doi:10.1029/2003JD004047, 2004.

Andreae, M. O., Anderson, B. E., Blake, D. R., Bradshaw, J. D., Collins, J. E., Gregory, G. L., Sachse, G. W., and Shipham, M.
C.: Influence of plumes from biomass burning on atmospheric chemistry over the equatorial and tropical South Atlantic during CITE3, J. Geophys. Res., 99, 12 793-12 808, 1994.

Andreae, M. O. and Merlet, P.: Emission of trace gases and aerosols from biomass burning, Global Biogeochem. Cycles, 15, 955966, 2001.

Barrie, L. A.: Arctic air pollution - an overview of current knowledge, Atmos. Environ., 20, 643-663, 1986.

Berg, T., Sekkesæter, Steinnes, E., Valdal, A.-K., and Wibetoe, G.: Springtime depletion of mercury in the European Arctic as observed at Svalbard, Sci. Total Env., 304, 43-51, 2003.

Birch, M. E. and Cary, R. A.: Elemental carbon-based method for monitoring occupational exposures to particulate diesel exhaust, Aersosol Sci. Technol., 25, 221-241, 1996.

Bond, T. C. and Bergstrom, R. W.: Light absorption by carbonaceous particles: An investigative review, Aerosol Sci. Technol., 39, 1-41, 2005.

Bradley, R. S., Keimig, F. T., and Diaz, H. F.: Climatology of surface-based inversions in the North American Arctic, J. Geophys. Res., 97, 15 699-15 712, 1992.

Brunke, E.-G., Labuschagne, C., and Slemr, F.: Gaseous mercury emissions from a fire in the Cape Peninsula, South Africa, during January 2000, Geophys. Res. Lett., 28, 1483-1486, 2001.

Campbell, J. R., Hlavka, D. L., Welton, E. J., Flynn, C. J., Turner, D. D., Spinhirne, J. D., Scott, V. S., and Hwang, I. H.: Full-time eye-safe cloud and aerosol lidar observation at Atmospheric Radiation Measurement program sites: Instruments and data processing, J. Atmos. Oceanic Technol., 19, 431-442, 2002.

Carlson, T. N.: Speculations on the movement of polluted air to the Arctic, Atmos. Environ., 15, 1473-1477, 1981.

Covert, D. S. and Heintzenberg, J.: Size distributions and chemical properties of aerosol at Ny Ålesund, Svalbard, Atmos. Environ., 27A, 2989-2997, 1993.

Damoah, R., Spichtinger, N., Forster, C., James, P., Mattis, I., Wandinger, U., Beirle, S., and Stohl, A.: Around the world in 17 days - hemispheric-scale transport of forest fire smoke from Russia in May 2003, Atmos. Chem. Phys., 4, 1311-1321, 2004, http://www.atmos-chem-phys.net/4/1311/2004/.

Dye, C. and Yttri, K. E.: Determination of monosaccharide anhydrides in atmospheric aerosols by use of high-resolution mass spectrometry combined with high performance liquid chromatography, Anal. Chem., 77, 1853-1858, 2005.

Echalar, F., Gaudichet, A., Cachier, H., and Artaxo, P.: Aerosol emissions by tropical forest and savanna biomass burning: characteristic trace elements and fluxes, Geophys. Res. Lett., 22, 3039-3042, 1995.

Eckhardt, S., Stohl, A., Beirle, S., Spichtinger, N., James, P., Forster, C., Junker, C., Wagner, T., Platt, U., and Jennings, S. G.: The North Atlantic Oscillation controls air pollution transport to the Arctic, Atmos. Chem. Phys., 3, 1769-1778, 2003, http://www.atmos-chem-phys.net/3/1769/2003/.

ECMWF (White, P. W., Ed.): IFS Documentation, ECMWF, Reading, UK, 2002.

Emanuel, K. A., and Živković-Rothman, M.: Development and evaluation of a convection scheme for use in climate models, J. Atmos. Sci., 56, 1766-1782, 1999.

Forster, C., Wandinger, U., Wotawa, G., James, P., Mattis, I., Althausen, D., Simmonds, P., O'Doherty, S., Kleefeld, C., Jennings, S. G., Schneider, J., Trickl, T., Kreipl, S., Jäger, H., and 
Stohl, A.: Transport of boreal forest fire emissions from Canada to Europe, J. Geophys. Res., 106, 22 887-22 906, 2001.

Forster, C., Stohl, A., and Seibert, P.: Parameterization of convective transport in a Lagrangian particle dispersion model and its evaluation, J. Appl. Meteor., in press, 2006.

Francey, R. J., Steele, L. P., Langenfelds, R. L., Lucarelli, M. P., Allison, C. E., Beardsmore, D. J., Coram, S. A., Derek, N., deSilva, F. R., Etheridge, D. M., Fraser, P. J., Henry, R. J., Turner, B., Welch, E. D., Spencer, D. A., and Cooper, L. N., Global Atmospheric Sampling Laboratory (GASLAB): supporting and extending the Cape Grim trace gas programs, Baseline Atmospheric Program (Australia) 1993, edited by: Francey, R. J., Dick, A. L., and Derek, N., Bureau of Meteorology and CSIRO Division of Atmospheric Research, Melbourne, Australia, pp. 829, 1996.

Friedli, H. R., Radke, L. F., Prescott, R., Hobbs, P. V., and Sinha, P: Mercury emissions from the August 2001 wildfires in Washington State and an agricultural waste fire in Oregon and atmospheric mercury budget estimates, Global Biogeochem. Cycles, 17, 1039, doi:10.1029/2002GB001972, 2003.

Friedli, H. R., Radke, L. F., Lu, J. Y., Banic, C. M., Leaitch, W. R., and MacPherson, J. I.: Mercury emissions from burning of biomass from temperate North American forests: laboratory and airborne measurements, Atmos. Environ., 37, 253-267, 2003.

Giglio, L., Descloitres, J., Justice, C. O., and Kaufman, Y.: An enhanced contextual fire detection algorithm for MODIS, Rem. Sens. Environ., 87, 273-282, 2003.

Greenaway, K. R.: Experiences with Arctic flying weather, Royal Meteorological Society Canadian Branch (30 November 1950), Toronto, Ontario, Canada, 1950.

Hansen, J., and Nazarenko, L.: Soot climate forcing via snow and ice albedos, Proc. Natl. Acad. Sci. USA, 101, 423-428, doi:10.1073/pnas.2237157100, 2004.

Hansen, M., DeFries, R., Townshend, J. R. G., and Sohlberg, R.: Global land cover classification at $1 \mathrm{~km}$ resolution using a decision tree classifier, Intern. J. Rem. Sensing., 21, 1331-1365, 2000.

Hays, M. D., Fine, P. M., Geron, C. D., Kleeman, M. J., and Gullett, B. K.: Open burning of agricultural biomass: Physical and chemical properties of particle-phase emissions, Atmos. Environ., 39, 6747-6764, 2005.

Hegg, D. A., Radke, L. F., Hobbs, P. V., and Brock, C. A.: Nitrogen and sulfur emissions from the burning of forest products near large urban areas, J. Geophys. Res., 92, 14 701-14 709, 1987.

Herber, A., Thomason, L. W., Gernandt, H., Leiterer, U., Nagel, D., Schulz, K.-H., Kaptur, J., Albrecht, T., and Notholt, J.: Continuous day and night aerosol optical depth observations in the Arctic between 1991 and 1999, J. Geophys. Res., 107, 4097, doi:10.1029/2001JD000536, 2002.

Holmes B. J. and Petrucci, G. A.: Water-soluble oligomer formation from acid-catalyzed reactions of levoglucosan in proxies of atmospheric aqueous aerosols, Environ. Sci. Technol., 40, 49834989, 2006.

Honrath, R. E., Owen, R. C., Val Martin, M., Reid, J. S., Lapina, K., Fialho, P., Dziobak, M. P., Kleissl, J., and Westphal, D. L.: Regional and hemispheric impacts of anthropogenic and biomass burning emissions on summertime $\mathrm{CO}$ and $\mathrm{O}_{3}$ in the North Atlantic lower free troposphere, J. Geophys. Res., 109, D24310, doi:10.1029/2004JD005147, 2004.
Ichoku, C., Remer, L. A., and Eck, T. F.: Quantitative evaluation and intercomparison of morning and afternoon Moderate Resolution Imaging Spectroradiometer (MODIS) aerosol measurements from Terra and Aqua, J. Geophys. Res., 110, D10S03, doi:10.1029/2004JD004987, 2005.

Iversen, T.: On the atmospheric transport of pollution to the Arctic, Geophys. Res. Lett., 11, 457-460, 1984.

Iversen, T. and Joranger, E: Arctic air pollution and large scale atmospheric flows, Atmos. Environ., 19, 2099-2108, 1985.

Jauhiainen, T., Moore, J., Peramaki, P., Derome, J., and Derome, K.: Simple procedure for ion chromatographic determination of anion and cations at trace levels in ice core samples, Anal. Chim. Acta, 389, 21-29, 1999.

Jokinen, V. and Makela, J. M.: Closed-loop arrangement with critical orifice for DMA sheath excess flow system, J. Aerosol Sci., 28, 643-648, 1997.

Kekonen, T., Moore, J. C., Mulvaney, R., Isaksson, E., Pohjola, V., and v.d. Wal, R. S. W.: A 800 year record of nitrate from the Lomonosovfonna ice core, Svalbard, Ann. Glaciol., 35, 261-265, 2002.

Kekonen, T., Peramaki, P., and Moore, J. C.: Comparison of analytical results for chloride, sulfate and nitrate obtained from adjacent ice core samples by two ion chromatographic methods. J Environ. Mon., 6, 147-152, doi:10.1039/B306621E, 2004.

Khalil, M. A. K. and Rasmussen, R. A.: Atmospheric methyl chloride, Atmos. Env., 33, 1305-1321, 1999.

Khalil, M. A. K. and Rasmussen, R. A.: Tracers of wood smoke, Atmos. Env., 37, 1211-1222, 2003.

Knutson, E. O. and Whitby, K. T.: Aerosol classification by electric mobility: Apparatus, theory and applications, J. Aerosol Sci., 6, 443-451, 1975.

Klonecki, A., Hess, P., Emmons, L., Smith, L., Orlando, J., and Blake, D.: Seasonal changes in the transport of pollutants into the Arctic troposphere - model study, J. Geophys. Res., 108, 8367, doi:10.1029/2002JD002199, 2003.

Korontzi, S., McCarty, J., Loboda, T., Kumar, S., and Justice, C.: Global distribution of agricultural fires in croplands from 3 years of Moderate Resolution Imaging Spectroradiometer (MODIS) data, Global Biogeochem. Cycles, 20, GB2021, doi:10.1029/2005GB002529, 2006.

Langenfelds, R. L., Steele, L. P., Cooper, L. N., Spencer, D. A., Etheridge, D. M., and Lucarelli, M. P.: CSIRO GASLAB measurement of $\mathrm{CO}_{2}, \mathrm{CH}_{4}, \mathrm{CO}, \mathrm{H}_{2}$ and $\mathrm{N}_{2} \mathrm{O}$ by gas chromatography, CSIRO Atmospheric Research technical report, 1999.

Langmann, B. and Graf, H.: Indonesian smoke aerosols from peat fires and the contribution from volcanic sulfur emissions Geophys. Res. Lett., 30, 1547, doi:10.1029/2002GL016646, 2003.

Lavoué, D.: Transport to the Arctic region of carbon aerosols emitted by biomass burning in boreal and temperate regions (in French; Transport vers la région arctique de l'aérosol carboné émis par les feux de biomasse des régions boréale et tempérée). $\mathrm{PhD}$ thesis at the University of Paris VII, 2000.

Lavoué, D., Liousse, C., Cachier, H., Stocks, B. J., and Goldammer, J. G.: Modeling of carbonaceous particles emitted by boreal and temperate wildfires at northern latitudes, J. Geophys. Res., 105, 26871-26890, 2000.

Leiterer, U. and Weller, M.: Sun photometer BAS/ABAS for Atmospheric Research, WMO/TD, 222, 21-26, 1988.

Lindberg, S. E., Brooks, S., Lin, C.-J., Scott, K. J., Landis, M. S., 
Stevens, R. K., Goodsite, M., and Richter, A.: Dynamic oxidation of gaseous mercury in the Arctic troposphere at polar sunrise, Environ. Sci. Tech., 36, 1245-1256, 2002.

McMillan, W. W., Barnet, C., Strow, L., Chahine, M. T., McCourt Comer, M., Novelli, P. C., Krontzi, S., Maddy, E. S., and Datta, S.: Daily Global Maps of Carbon Monoxide: First Views from NASA's Atmospheric Ifrared Sounder, Geophys. Res. Lett., 32, L11801, doi:10.1029/2004GL012821, 2005.

Meteorological Institue: Weather in Norway, monthly climatological overview (in Norwegian: Været i Norge, Klimatologisk Månedsoversikt). Meteorologisk institutt, Oslo, ISSN 1503-8017, nr. 01-05/2006, available from http://met.no/ observasjoner/maned/index.html, 2006.

Mitchell, J. M.: Visual range in the polar regions with particular reference to the Alaskan Arctic, J. Atmos. Terr. Phys., Special Suppl., 195-211, 1957.

Mylona, S.: Sulphur dioxide emissions in Europe 1880-1991 and their effect on sulphur concentrations and depositions, Tellus, 48B, 662-689, 1996.

Niemi, J. V., Tervahattu, H., Vehkamäki, H., Kulmala, M., Koskentalo, T., Sillanpää, M., and Rantamäki, M.: Characterization and source identification of a fine particle episode in Finland, Atmos. Environ., 38, 5003-5012, 2004.

Olivier, J. G. J. and Berdowski, J. J. M.: Global emissions sources and sinks, in: The Climate System, edited by: Berdowski, J., Guicherit, R., and Heij, B. J., A.A. Balkema Publishers/Swets \& Zeitlinger Publishers, Lisse, The Netherlands, ISBN 905809 255 0, pp. 33-78, 2001.

Parrish, D. D., Holloway, J. S., Trainer, M., Murphy, P. C., Forbers, G. L., and Fehsenfeld, F. C.: Relationships between ozone and carbon monoxide at surface sites in the North Atlantic region, J. Geophys. Res., 103, 13 357-13 376, 1998.

Pavlidis, T.: Computer filling in raster graphics, Computer Graphics 15, 29-36, 1981.

Prinn, R. G., Weiss, R. F., Fraser, P. J., Simmonds, P. G., Cunnold, D. M., et al.: A history of chemically and radiatively important trace gases in air deduced from ALE/GAGE/AGAGE, J. Geophys. Res., 105, 17 751-17 792, 2000.

Raatz, W. E. and Shaw, G. E.: Long-range tropospheric transport of pollution aerosols into the Alaskan Arctic, J. Clim. Appl. Meteor., 23, 1052-1064, 1984.

Rahn, K. A.: Relative importance of North America and Eurasia as sources of Arctic aerosol, Atmos. Environ., 15, 1447-1455, 1981.

Real, E., Law, K. S., Weinzierl, B., Fiebig, M., Petzold, A., Wild, O., Methven, J., Arnold, S., Stohl, A., Huntrieser, H., Roiger, A., Schlager, H., Stewart, D., Avery, M., Sachse, G., Browell, E., Ferrare, R., and Blake D.: Processes influencing ozone levels in Alaskan forest fire plumes during long-range transport over the North Atlantic, J. Geophys. Res., in press, 2006.

Reimann, S., Schaub, D., Stemmler, K., Folini, D., Hill, M., Hofer, P., Buchmann, B., Simmonds, P. G., Greally, B. R., and O'Doherty, S.: Halogenated greenhouse gases at the Swiss high Alpine site of Jungfraujoch (3580 m asl): Continuous measurements and their use for regional European source allocation, J. Geophys. Res., 109, D05307, doi:10.1029/2003JD003923, 2004.

Remer, L. A., Kaufman, Y. J., Tanré, D., Mattoo, S., Chu, D. A., Martins, J. V., Li, R.-R., Ichoku, C., Levy, R. C., Kleidman, R. G., Eck, T. F., Vermote, E., and Holben, B. N.: The MODIS aerosol algorithm, products, and validation, J. Atmos. Sci., 62, 947-973, 2005.

Seibert, P. and Frank, A.: Source-receptor matrix calculation with a Lagrangian particle dispersion model in backward mode, Atmos. Chem. Phys., 4, 51-63, 2004,

http://www.atmos-chem-phys.net/4/51/2004/.

Seiler, W. and Crutzen, P. J.: Estimates of gross and net fluxes of carbon between the biosphere and atmosphere from biomass burning, Clim. Change, 2, 207-247, 1980.

Shaw, G. E.: The Arctic Haze phenomenon, Bull. Amer. Meteorol. Soc., 76, 2403-2412, 1995.

Shipham, M. C., Bachmeier, A. S., Cahoon Jr., D. R., and Browell, E. V.: Meteorological overview of the Arctic Boundary Layer Expedition (ABLE 3A) flight series, J. Geophys. Res., 97, 16395-16419, 1992.

Sigler, J. M., Lee, X., and Munger, W.: Emission and long-range transport of gaseous mercury from a large-scale Canadian boreal forest fire, Environ. Sci. Technol., 37, 4343-4347.

Simmonds, P. G., O’Doherty, S., Nickless, G., Sturrock, G. A., Swaby, R., Knight, A., Ricketts, J., Woffendin, G., and Smith, R.: Automated gas chromatograph mass-spectrometer for routine atmospheric field measurements of the CFC replacement compounds, the hydrofluorocarbons and the hydrofluorochlorocarbons, Anal. Chem., 67, 717-723.

Simoneit, B. R. T., Schauer, J. J., Nolte, C. G., Oros, D. R., Elias, V. O., Fraser, M. P., Rogge, W. F., and Cass, G. R.: Levoglucosan, a tracer for cellulose in biomass burning and atmospheric particles, Atmos. Environ., 33, 173-182, 1999.

Simpson, D., Fagerli, H., Jonson, J. E., Tsyro, S., Wind, P., and Tuovinen, J.-P.: The EMEP Unified Eulerian Model. Model Description, EMEP MSC-W Report 1/2003, The Norwegian Meteorological Institute, Oslo, Norway, 2003.

Solberg, S., Dye, C., and Schmidbauer, N.: Carbonyls and nonmethane hydrocarbons at rural European sites from the Mediterranean to the Arctic, J. Atmos. Chem., 25, 33-66, 1996.

Stohl, A., Williams, E., Wotawa, G., and Kromp-Kolb, H: A European inventory of soil nitric oxide emissions and the effect of these emissions on the photochemical formation of ozone in Europe, Atmos. Environ., 30, 3741-3755, 1996.

Stohl, A.: Characteristics of atmospheric transport into the Arctic troposphere, J. Geophys. Res., 111, D11306, doi:10.1029/2005JD006888, 2006.

Stohl, A., Hittenberger, M., and Wotawa, G.: Validation of the Lagrangian particle dispersion model FLEXPART against large scale tracer experiment data, Atmos. Environ., 32, 4245-4264, 1998.

Stohl, A. and Thomson, D. J.: A density correction for Lagrangian particle dispersion models, Boundary-Layer Meteorol., 90, 155167, 1999.

Stohl, A., Forster, C. Eckhardt, S., Spichtinger, N., Huntrieser, H., Heland, J., Schlager, H., Wilhelm, S., Arnold, F., and Cooper, O.: A backward modeling study of intercontinental pollution transport using aircraft measurements, J. Geophys. Res., 108, 4370, doi:10.1029/2002JD002862, 2003.

Stohl, A., Forster, C., Frank, A., Seibert, P., and Wotawa, G.: Technical note: The Lagrangian particle dispersion model FLEXPART version 6.2., Atmos. Chem. Phys., 5, 2461-2474, 2005, http://www.atmos-chem-phys.net/5/2461/2005/.

Stohl, A., Andrews, E., Burkhart, J. F., Forster, C., Herber, A., 
Hoch, S. W. , Kowal, D., Lunder, C., Mefford, T., Ogren, J. A., Sharma, S., Spichtinger, N., Stebel, K., Stone, R., Ström, J., Tørseth, K., Wehrli, C., and Yttri, K. E.: Pan-Arctic enhancements of light absorbing aerosol concentrations due to North American boreal forest fires during summer 2004, J. Geophys. Res. 111, D22214, doi:10.1029/2006JD007216, 2006.

Ström, J., Umegård, J., Tørseth, K., Tunved, P., Hansson, H.-C., Holmén, K., Wismann, V., Herber, A., and König-Langlo, G.: One year of particle size distribution and aerosol chemical composition measurements at the Zeppelin Station, Svalbard, March 2000-March 2001, Phys. Chem. Earth, 28, 1181-1190, 2003.

Vasic, A.-M. and Weilenmann, M.: Comparison of real-world emissions from two-wheelers and passenger cars, Environ. Sci. Technol., 40, 149-154, 2006.

Vestreng, V., Breivik, K., Adams, M. Wagner, A., Goodwin, J., Rozovskaya, O., and Pacyna, J. M.: Emission data reported to LRTAP Convention and NEC Directive - Initial review for HMs and POPs, EMEP Report 2005, Norwegian Meteorological Institute, ISSN 0804-2446, 2005.

Welton, E. J., Campbell, J. R., Spinhirne, J. D., and Scott, V. S.: Global monitoring of clouds and aerosols using a network of micro-pulse lidar systems, Proc. Int. Soc. Opt. Eng., 4153, 151158, 2001.
Wiedinmyer, C., Quayle, B., Geron, C., Belote, A., McKenzie, D., Zhang, X., O’Neill, S., and Wynne, K. K.: Estimating emissions from fires in North America for air quality modeling, Atmos. Environ., 40, 3419-3432, 2006.

World Meteorological Organization (WMO): IPCC/TEAP Special Report on Safeguarding the Ozone Layer and the Global Climate System: Issues Related to Hydrofluorocarbons and Perfluorocarbons, ISBN 92-9169-118-6, World Meteorological Organization, Geneva, 2005.

Wofsy, S. C., Sachse, G. W., Gregory, G. L., Blake, D. R., Bradshaw, J. D., et al.: Atmospheric chemistry in the Arctic and Subarctic: Influence of natural fires, industrial emissions, and stratospheric inputs, J. Geophys. Res., 97, 16 721-16 746, 1992.

Wotawa, G. and Trainer, M.: The Influence of Canadian Forest Fires on Pollutant Concentrations in the United States, Science, 288, 324-328, 2000.

Wotawa, G., De Geer, L.-E., Becker, A., D’Amours, R., Jean, M., Servranckx, R., and Ungar, K.: Inter- and intra-continental transport of radioactive cesium released by boreal forest fires, Geophys. Res. Lett., 33, L12806, doi:10.1029/2006GL026206, 2006.

Yurganov, L. N., Grechko, E. I., and Dzhola, A. V.: Carbon monoxide and total ozone in Arctic and Antarctic regions: seasonal variations, long-term trends and relationships, Sci. Tot. Environ., 160/161, 831-840, 1995. 